\title{
Oxidation and Reduction of Iron-Titanium Oxides in Chemical Looping Combustion: A Phase-Chemical Description
}

\author{
P. den Hoed ${ }^{*}$ and A. Luckos ${ }^{2}$ \\ 1 Anglo Research, 8 Schonland Street, Theta 2091, Johannesburg - South Africa \\ 2 Sasol Technology, Sasolburg - South Africa \\ e-mail: pdenhoed@angloresearch.com - adam.luckos@sasol.com \\ * Corresponding author
}

\begin{abstract}
Résumé - Oxydation et réduction des minerais de fer-titane dans la combustion en boucle chimique - L'ilménite $\left(\mathrm{FeTiO}_{3}\right)$ est considéré comme un transporteur d'oxygène potentiel pour les procédés en boucle chimique. Ses mécanismes de réduction et d'oxydation sont décrits à travers le système $\mathrm{Fe}-\mathrm{Fe}_{2} \mathrm{O}_{3}-\mathrm{TiO}_{2}-\mathrm{TiO}_{3}$. Le diagramme de phase à $1000^{\circ} \mathrm{C}$, présenté ici, est un outil utile pour prédire les réactions et les produits. Nous constatons que $\mathrm{Fe}_{2} \mathrm{TiO}_{5}$ (pseudobrookite) et $\mathrm{TiO}_{2}$ (rutile) forment un assemblage de phase stable après oxydation de l'ilménite $\left(\mathrm{FeTiO}_{3}\right)$ dans l'air. La réduction subséquente de $\mathrm{Fe}_{2} \mathrm{TiO}_{5}$ à la pression partielle de $10^{-15,5} \mathrm{~atm}$ stabilise vers $\mathrm{Fe}_{1.02} \mathrm{Ti}_{0.98} \mathrm{O}_{3}$, une solution solide d'ilménite. Une réduction plus poussée va produire du fer métallique et compromettre l'intégrité du transporteur d'oxygène dans la boucle chimique. Il est probable que la réduction des oxydes Fe-Ti ne soit pas, en pratique, complète et n'atteigne pas l'équilibre dans les conditions rencontrées en opération dans les réacteurs de réduction.
\end{abstract}

\footnotetext{
Abstract - Oxidation and Reduction of Iron-Titanium Oxides in Chemical Looping Combustion: A Phase-Chemical Description - Ilmenite $\left(\mathrm{FeTiO}_{3}\right)$ is being explored as an oxygen carrier in chemical looping processes. Its reduction and oxidation are described by the system $\mathrm{Fe}_{-} \mathrm{Fe}_{2} \mathrm{O}_{3}-\mathrm{TiO}_{2}-\mathrm{Ti}_{2} \mathrm{O}_{3}$. The phase diagram at $1000^{\circ} \mathrm{C}$, presented here, offers a useful tool for predicting reactions and their products. We see that $\mathrm{Fe}_{2} \mathrm{TiO}_{5}$ (pseudobrookite) and $\mathrm{TiO}_{2}$ (rutile) form a stable phase assemblage following the oxidation of $\mathrm{FeTiO}_{3}$ (ilmenite) in air. The subsequent reduction of $\mathrm{Fe}_{2} \mathrm{TiO}_{5}$ at oxygen partial pressures of $10^{-15.5}$ atm stabilizes $\mathrm{Fe}_{1.02} \mathrm{Ti}_{0.98} \mathrm{O}_{3}$, a solid solution of ilmenite. Further reduction will produce metallic iron, which compromises the integrity of the oxygen carrier for chemical looping processes. We speculate that the reduction of Fe-Ti oxides in several practical instances does not reach completion (and equilibrium) under the imposed atmospheres operating in fuel reactors.
} 


\section{INTRODUCTION}

How oxygen carriers behave in chemical looping combustion and gasification is critical to the success of these processes. Besides fluidizing well, carriers should exhibit high reactivity, good mechanical strength, and resistance to attrition and agglomeration; the particles should retain their integrity. If, furthermore, a carrier is cheap, not toxic, and does not require priming, then so much the better (see Lyngfelt, 2010). The mineral ilmenite (nominally denoted by $\mathrm{FeTiO}_{3}$ ) meets these criteria, albeit to varying degrees (see Berguerand and Lyngfelt, 2008a, b, 2009, 2010; Leion et al., 2008a, b, 2009; Mayer et al., 2008; Kolbitsch et al., 2009; Pröll et al., 2009; Adánez et al., 2010; Cuadrat et al., 2010; Lyngfelt, 2010; Perrault et al., 2010; Schwebel et al., 2010; cf. Jerndal et $a l$. , in press). As such it is a promising candidate. Several of the research teams are focusing their efforts in exploring its efficacy.

Ilmenite has, however, another commercial and academic history. For many decades it has been the primary source of titanium in the manufacture of $\mathrm{TiO}_{2}$ pigments (see Den Hoed, 1993, pp. 2-13). In the decades following the First World War ilmenite was mined as a raw material for the sulfate process, the first of two processes developed to manufacture $\mathrm{TiO}_{2}$ pigments (ibid.). In the 1950s two Canadian companies, QIT-Fer et Titane (Quebec Iron and Titanium Ltd) and Hatch, developed a smelting process for producing a titaniumrich (nominally $72 \% \mathrm{TiO}_{2}$ ) slag for the sulfate process. Pig iron was a saleable byproduct of the process, and the lower iron content of the slag reduced the quantities of effluent discharged from pigment plants treating this slag. In subsequent years, this technology was developed further to produce higher grades of slag - i.e., of nominal $86 \% \mathrm{TiO}_{2}$. When the American industrial giant E.I. du Pont de Nemours and Co. developed the chloride process of pigment manufacture in the early 1960s, titaniferous slags made suitable feedstock to the process. Smelting concentrates of ilmenite made economic sense in Canada and, starting in the late 1970s, in South Africa: electricity was comparatively cheap, as it is in Norway, which also developed a smelting technology for upgrading local ilmenite concentrates. Australia, on the other hand, followed a different route in the chemical beneficiation of ilmenite. Researchers at the Government Chemical Laboratories of the Western Australian Department of Mines developed the eponymous Becher process (Becher, 1963). It was subsequently improved upon by engineers and scientists at Western Titanium Limited (WTL) and CSIRO. In the process reduction of pre-oxidized ilmenite takes place at subsolidus $\left(\sim 1200^{\circ} \mathrm{C}\right)$ temperatures, and metallic iron is removed from the oxide by leaching in water under oxidizing conditions. The product is a "synthetic rutile"; it contains 91-93\% $\mathrm{TiO}_{2}$. WTL began commercial production in 1974, following several years of pilot-plant production. And thus matters have remained for the last three decades: concentrates of ilmenite are reduced either by smelting or in the solid state, and the titanium-rich oxide (either slag, perhaps upgraded, or synthetic rutile) serves as feed for the manufacture of $\mathrm{TiO}_{2}$ pigment.

The associated academic history, however, is of greater importance to us. Concomitant with the two metallurgical developments - i.e., those of QIT and WTL - and partly prompted by a need to understand the reduction reaction in the WTL process, teams of scientists identified the stable phases present in the system $\mathrm{Fe}-\mathrm{Ti}-\mathrm{O}^{1}$ and determined the conditions under which they co-exist at equilibrium. These scientists knew the value of knowing what phases occur in the Fe-Ti-O system and how they co-exist. They understood the implications. Placing ilmenite in the presence of enough carbon at high temperatures produces continuous chemical and structural changes in the metal oxide until a terminal condition is reached. All reaction ceases at this point, as does the tendency for further reaction; the chemical species of the reaction are at equilibrium with each other. The fixing of the position of equilibrium, moreover, determines the direction the reaction must take to reach it. The prevailing conditions of temperature and carbon impose a final state on the reaction, thereby setting a maximum on the conversion that ilmenite can undergo in reduction. Industrial importance attaches to this particular state, for it stands in relation to a goal - such as the complete reduction of all oxygen-bonded iron to metal in the metallurgical processing of ilmenite, or the incomplete reduction of a titaniferous oxide in chemical looping combustion and so provides a measure of the value that can be extracted from an ore.

But specific conditions fix more than the final state of a reaction; they fix the path a reaction follows. Between the initial and final states of the reaction are an infinite number of other states, each one uniquely defined. It is possible to control a reaction and force it to change incrementally, never removing it more than differentially from equilibrium. A reaction will then pass through all the intermediate states at an infinitesimal rate. Buchdahl (1966, pp. 7-8) calls this a "pseudo-static" transition; it is also a reversible reaction. Such transitions are often predicted by means of phase diagrams, thermodynamic representations not unlike a map: the topography locates the phase assemblages of a multicomponent system on a coordinate grid of chemical composition; superimposed on these two dimensions are the contours of oxygen isobars (in oxide systems) and, in binary systems, isotherms. Oxygen fugacity and temperature are two extensive variables in the system (Muan, 1958, pp. 172-173). A reversible reaction traverses this topography along a set path, at each point maintaining an equilibrium between species in all phases through which the path cuts. At every

\footnotetext{
1 As many ilmenites of beach-sand origin contain manganese and magnesium in solid solution, so the measurement of phase equilibria was extended to include the systems $\mathrm{Fe}-(\mathrm{Mn}, \mathrm{Mg})-\mathrm{Ti}-\mathrm{O}$.
} 
point on the path the equilibrium phase assemblage, its composition, and the temperature and oxygen partial pressure at which it is stable are all fixed and known from the diagram.

The focus in industrial processes, however, is on the conditions that define the initial and final states of a reaction rather than the reversible path between them. Should reactions be allowed to run their course, as they so often are in metallurgical systems undergoing reduction at high temperatures, then they will approach, if not attain, equilibrium. Phase diagrams let us know what final assemblage of phases to expect (the phases at equilibrium being related to extensive variables in the system); what the compositions of those phases will be; and what fraction of iron, in reduction, has been reduced, or what the ratio of ferric and ferrous ions will be following reduction or oxidation. Underlying these questions is a practical need, that the likely outcome of reduction or oxidation (the final point of equilibrium) be close to a desired goal. In chemical looping combustion or gasification that goal will be achieved by swinging as much iron as possible between oxidation states (i.e., $\mathrm{Fe}^{2+}$ and $\mathrm{Fe}^{3+}$ ) without destroying the competence of the oxide particles. In this paper, we show by means of phase diagrams what changes iron and the phases it occupies undergo during cycles of oxidation and reduction in chemical looping processes. We review what is known of phase equilibria in the system $\mathrm{Fe}-\mathrm{Ti}-\mathrm{O}-$ in particular, those equilibria relating to conditions that prevail in processes in chemical looping combustion and gasification. Through the phase diagrams that express these equilibria we can establish limits on the conditions under which chemical looping processes should operate to be effective; we can identify conditions that should be avoided, and determine what changes in phase-chemical composition to expect; and, finally, we can relate these changes to the effectiveness of ilmenite as an oxygen carrier.

\section{PHASE EQUILIBRIA}

The phase relations in oxide systems Fe-Ti-O and $\mathrm{Fe}-(\mathrm{Mn}, \mathrm{Mg})-\mathrm{Ti}-\mathrm{O}$ systems set at high temperatures and under strongly reducing conditions have been the object of detailed study. Our knowledge of their phase relations and concomitant oxygen potentials derives chiefly from the work of three research teams:

- at the CSIRO in Melbourne during the 1970s (Reid and Ward, 1971; Grey and Ward, 1973; Grey et al., 1974a, b, 1976; Merritt and Turnbull, 1974; Grey and Merritt, 1981). Also from south-eastern Australia comes the more recent contribution of O'Neill et al. (1988);

- at the Aachen University of Technology, North RhineWestphalia (Simons and Woermann, 1978; Ender et al., 1980; Eriksson et al., 1996);

- at the Norwegian Institute of Technology, Trondheim, in the 1980s (Borowiec and Rosenqvist, 1981, 1982, 1985).
Their data are inscribed graphically in ways that reflect what is known about all the variables. Some inscriptions are more complete than others. Thus, chemical compositions are ignored when, for certain phase assemblages - those constrained by the phase rule to one degree of freedom - the change in oxygen fugacity is plotted against temperature (see Grey and Merritt, 1981: Fig. 2; Borowiec and Rosenqvist, 1981: Fig. 4, 5; 1985: Fig. 23; see also Saha and Biggar, 1974: Fig. 2-5, and Anovitz et al., 1985: Fig. 2, 3). Where the electrochemical technique has been used, oxygen potential $\left(\mu_{\mathrm{O}_{2}}\right)$ may be quoted in place of fugacity (see Merritt and Turnbull, 1974: Fig. 2). On occasions, plots of this kind are regressed to equations (see Borowiec and Rosenqvist, 1981; O’Neill et al., 1988). Some phase equilibria are inscribed without recording oxygen fugacities, as when the composition at the solubility limit of a single-phase assemblage is plotted against temperature (see Ender et al., 1980: Fig. 1; Grey and Merritt, 1981: Fig. 3); the complementary inscription is isothermal, plotting phase compositions against oxygen fugacity (see Grey et al., 1974b: Fig. 4; 1976: Fig. 2-4; also Webster and Bright, 1961: Fig. 1, 3; cf. Merritt et al., 1973: Fig. 3-7). The latter are readily translated into phase diagrams.

The complete representation of phase relations in a ternary system at equilibrium and at one temperature can be constructed on a triangular base, where the co-ordinates mark composition, in units of either mole fraction or mass fraction (see Fig. la). Under conditions required to reduce ilmenite $\left(\mathrm{FeTiO}_{3}\right)$, the titaniferous oxides and their oxidation and reduction products, all part of the $\mathrm{Fe}-\mathrm{Ti}-\mathrm{O}$ system, occur exclusively in the quadrilateral region $\mathrm{Fe}-\mathrm{Fe}_{2} \mathrm{O}_{3}-\mathrm{TiO}_{2}-\mathrm{Ti}_{2} \mathrm{O}_{3}$. Oxide species, furthermore, remain within the bounds set by $\mathrm{FeO}-\mathrm{Fe}_{2} \mathrm{O}_{3}-\mathrm{TiO}_{2}-\mathrm{Ti}_{2} \mathrm{O}_{3}$, with naturally occurring oxides being bounded by the portion $\mathrm{FeO}-\mathrm{Fe}_{2} \mathrm{O}_{3}-\mathrm{TiO}_{2}$. As the oxide compositions are objects of study, it is common practice to display their spatial representations in a less crowded fashion. This is done by translating the $\mathrm{FeO}-\mathrm{Fe}_{2} \mathrm{O}_{3}-\mathrm{TiO}_{2}-\mathrm{Ti}_{2} \mathrm{O}_{3}$ domain into a rhombus (Saha and Biggar, 1974: p. 54, Fig. 7). The effect, attained through greater symmetry, is to open out the co-ordinates (see Fig. 1b).

The translation highlights a feature of the system, a set of three linear contours that mark compositions of constant molar cation-anion ratios. These contours lie parallel to one another and perpendicular to the $\mathrm{FeO}-\mathrm{TiO}_{2}$ join $^{2}$. Two (perhaps three) compositions on each contour point to stoichiometric versions of minerals. These are the end-members of three series, the length of each one mapping a continuous variation in the iron-titanium ratio. The three series, along with their cation-to-anion ratios, are:

- with a 3/5 ratio: $\mathrm{Fe}_{2} \mathrm{TiO}_{5}$ (pseudobrookite)- $\mathrm{FeTi}_{2} \mathrm{O}_{5}$ (ferrous pseudobrookite), and extending to $\mathrm{Ti}_{3} \mathrm{O}_{5}$;

\footnotetext{
2 Parallelism is retained in the translation by scaling by half the compositions at the extreme vertices, $\mathrm{Fe}_{2} \mathrm{O}_{3}$ and $\mathrm{Ti}_{2} \mathrm{O}_{3}$ (see Fig. 1 b) .
} 
a)
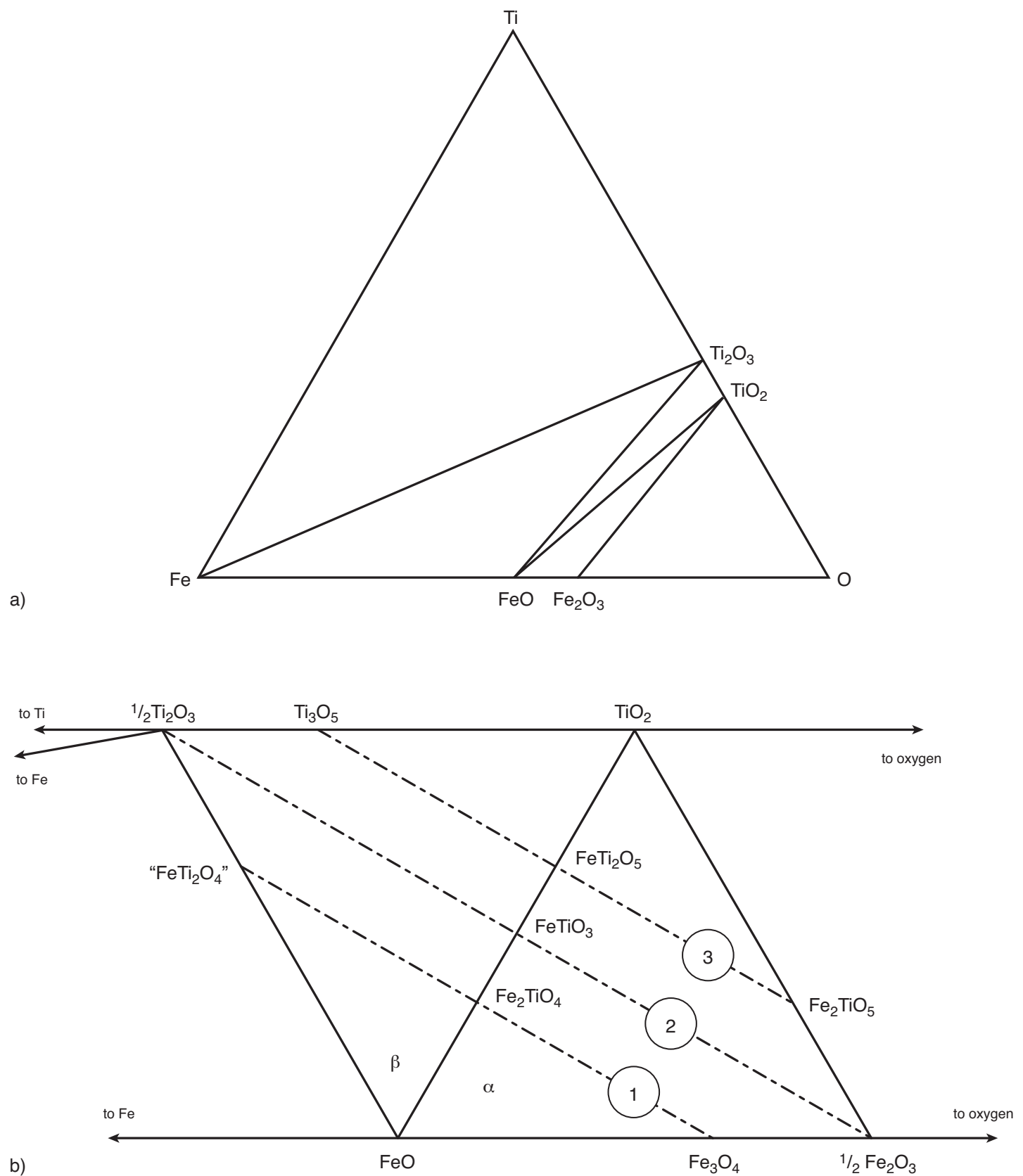

Figure 1

Co-ordinate construct for molar compositions in the Fe-Ti-O system. Region $\alpha$ is bounded by $\mathrm{FeO}_{2} \mathrm{Fe}_{2} \mathrm{O}_{3}$ and $\mathrm{TiO}_{2} ;$ region $\beta$, by FeO, TiO $\mathrm{Ti}_{2} \mathrm{O}_{3}$.

- with a $2 / 3$ ratio: $\mathrm{Fe}_{2} \mathrm{O}_{3}$ (hematite)- $\mathrm{FeTiO}_{3}$ (ilmenite); an extension to $\mathrm{Ti}_{2} \mathrm{O}_{3}$ is never realized;

- with a 3/4 ratio: $\mathrm{Fe}_{3} \mathrm{O}_{4}$ (magnetite)- $\mathrm{Fe}_{2} \mathrm{TiO}_{4}$ (ulvöspinel); the end-member $\mathrm{FeTi}_{2} \mathrm{O}_{4}$ does not exist.

As it stands, though, the diagram gives no information about the state of the system. Such information is derived from synthesis studies ( $c f$. Lindsley, 1991, p. 69), which create stable assemblages for a number of compositions (points on the diagram), identify their phases, analyse the chemical compositions of these phases, and measure the oxygen fugacity over each assemblage. This information, gathered at one temperature, is then superimposed on the compositional base 


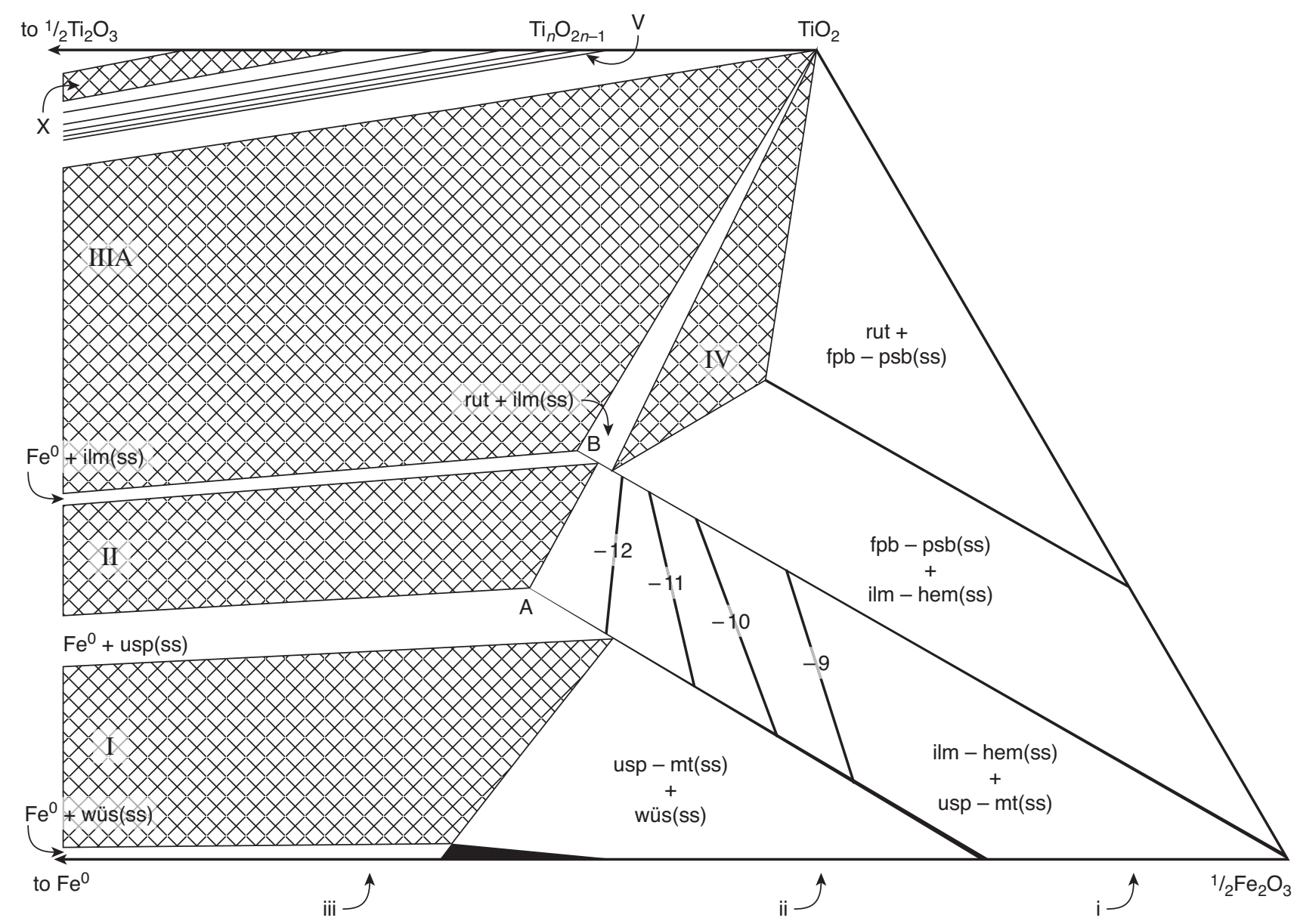

Figure 2

Phase relations in the system $\mathrm{Fe}-\mathrm{Fe}_{2} \mathrm{O}_{3}-\mathrm{TiO}_{2}-\mathrm{Ti}_{3} \mathrm{O}_{5}$ at $1000^{\circ} \mathrm{C}$ (molar basis). Invariant oxygen fugacities and phase compositions are listed in Table 2. Shown for two-phase spinel-rhombohedral assemblages are oxygen tie lines for fugacities $-12 \leq \log f_{\mathrm{O}_{2}} \leq-9$ (Spencer and Lindsley, 1981: Fig. 4). At $\mathrm{TiO}_{1.99}, \log f_{\mathrm{O}_{2}}=-18.0$ (Zador, 1968: Fig. 1, 4).

to produce a diagram of phase equilibria. We now detail the phase diagram for oxides and metallic iron in part of the Fe-Ti-O system at $1000^{\circ} \mathrm{C}$.

\section{PHASES AND ASSEMBLAGES}

The phase assemblages at equilibrium in the $\mathrm{Fe}-\mathrm{Fe}_{2} \mathrm{O}_{3}-\mathrm{TiO}_{2}$ $\mathrm{Ti}_{3} \mathrm{O}_{5}$ subsystem at $1000^{\circ} \mathrm{C}$ are depicted in Figure 2; abbreviations for the minerals and phases marked on the diagram are summarized in Table 1. (This temperature $\left(1000^{\circ} \mathrm{C}\right)$, for which we have phase diagrams, is close enough to the temperatures $\left(950^{\circ} \mathrm{C}\right)$ used in chemical looping combustion and so serves our purpose.) There are 13 different phases altogether: twelve of them are oxides, and among them are numbered six distinct titanium oxides; the thirteenth phase is metallic iron. Several of the oxides form solid solutions, extending as sin- gle phases over a range of compositions (bold lines or the solid parts marked in Fig. 2). Where regular cation substitutions produce extended compositional variations along contours of constant cation-anion ratios, the phase fields are termed solid-solution series ${ }^{3}$. Three examples, prevalent at higher temperatures, occur in the prominent oxides extending diagonally across the diagram; their lower (iron-richer) edges coincide with the three linear contours of constant cationanion ratio in Figure 1b. The phases are marked 1, 2, and $3^{4}$.

\footnotetext{
3 One of us some years ago had suggested an alternative label to the unwieldy term "solid-solution series", the monosyllabic word cline (see Den Hoed, 1993). It would convey the meaning of a graded series or continuum of compositions within an oxide phase; the gradation in composition is continuous and infinite along the locus between the end-members ( $c f$. OED, 1989). The word in its current sense was coined in a biological context by Julian Huxley (1938), and has subsequently been taken up in linguistics (see Halliday, 1961: p. 249; Crystal, 1985). Its meaning transfers readily to mineralogy.
} 
TABLE 1

Abbreviations of relevant oxide minerals and phases (Adapted from Lindsley, 1991: Tab. 1)

\begin{tabular}{|c|c|c|}
\hline Mineral/phase & Schematic formula & Abbreviation \\
\hline \multicolumn{3}{|l|}{ Spinel oxides } \\
\hline Magnetite & $\mathrm{Fe}_{3} \mathrm{O}_{4}$ & $\mathrm{mt}$ \\
\hline Ulvöspinel & $\mathrm{Fe}_{2} \mathrm{TiO}_{4}$ & usp \\
\hline - In general - & $M_{3} \mathrm{O}_{4}$ & - \\
\hline \multicolumn{3}{|l|}{ Rhombohedral oxides } \\
\hline Hematite & $\mathrm{Fe}_{2} \mathrm{O}_{3}$ & hem \\
\hline Ilmenite & $\mathrm{FeTiO}_{3}$ & ilm \\
\hline - In general - & $M_{2} \mathrm{O}_{3}$ & - \\
\hline \multicolumn{3}{|l|}{ Orthorhombic oxides } \\
\hline (Ferric) pseudobrookite & $\mathrm{Fe}_{2} \mathrm{TiO}_{5}$ & psb \\
\hline Ferrous pseudobrookite & $\mathrm{FeTi}_{2} \mathrm{O}_{5}$ & $\mathrm{fpb}$ \\
\hline Anosovite & $\mathrm{Ti}_{3} \mathrm{O}_{5}$ & ans \\
\hline - In general - & $M_{3} \mathrm{O}_{5}$ & - \\
\hline \multicolumn{3}{|l|}{ Others } \\
\hline Metallic iron & $\mathrm{Fe}$ & $\mathrm{Fe}^{0}$ \\
\hline Wüstite & $\mathrm{Fe}_{1-x} \mathrm{O}$ & wüs \\
\hline Rutile & $\mathrm{TiO}_{2}$ & rut \\
\hline Reduced rutile & $\mathrm{TiO}_{2-x}$ & rrt \\
\hline Magneli phases & $\mathrm{Ti}_{n} \mathrm{O}_{2 n-1}($ where $4 \leq n \leq 9)$ & $\mathrm{Mph}$ \\
\hline Carbon & $\mathrm{C}$ & $\mathrm{C}$ \\
\hline
\end{tabular}

The individual titaniferous solid-solution series are named either by end-member species or by crystal structure; they and are continuous only at high temperatures.

Magnetite-Ulvöspinel Solid-Solution Series, or spinel oxides. There are other labels identifying the series: titanomagnetites ( $c f$. Akimoto et al., 1957; Price, 1981) and titaniferous magnetites ( $c f$. MacChesney and Muan, 1959) are common designations. At low temperatures, the solid-solution series is interrupted by an asymmetric miscibility gap; the consolute temperature lies below $600^{\circ} \mathrm{C}$, perhaps even below $500^{\circ} \mathrm{C}$ (Vincent et al., 1957; Price, 1981; Lindsley, 1981, cf. 1991: p. 79; Spencer and Lindsley, 1981: Fig. 4). At $1000^{\circ} \mathrm{C}$, the solid-solution series is complete and has broadened to cation-deficient compositions (see Fig. 2). At higher temperatures, usp(ss) incorporates $\mathrm{Ti}^{3+}$, and the solid solution crosses into Region $\beta$. Below about $680^{\circ} \mathrm{C}$, usp(ss) no longer co-exists with $\mathrm{Fe}^{0}$ (Borowiec and Rosenqvist, 1981: p. 221).

Hematite-Ilmenite Solid-Solution Series, or rhombohedral oxides; also called $\alpha$-oxides (Webster and Bright, 1961; Lindsley, 1976a). Lindsley (1991: p. 79), concluding from the results of several studies, places the consolute point of the miscibility gap below $650^{\circ} \mathrm{C}$, lying asymmetrically towards

\footnotetext{
4 Solid solutions are indicated by the suffix (ss) appended to the abbreviation. Solid-solution series are likewise indicated, as in hem - ilm(ss) series. An oxide member at the ilmenite end of this series would be labelled ilm(ss). Texts generally have the indicator "ss" as a subscript (see, for instance, Lindsley, 1976b, 1991), but we have resorted to bracketing the designation ( $c f$. Grey et al., 1974a).
}

hematite; yet Borowiec and Rosenqvist (1981: Fig. 6) and Gupta et al. (1989a: Fig. 3) record a miscibility gap in the solid-solution series at $700^{\circ} \mathrm{C}$; this gap closes at $780^{\circ} \mathrm{C}$ (Borowiec and Rosenqvist, 1981: p. 221; 1985: p. 35). In the gap, two assemblages, each comprising phases from the three solid-solution series, are stable (Gupta et al., 1989a: Fig. 3), but there is "every reason to believe" that an assemblage of $\mathrm{ilm}(\mathrm{ss})$ and hem(ss) is "stable over a considerable temperature interval" below the consolute point (Lindsley, 1991: p. 86). Slow chemical-reaction rates are adduced to account for discrepancies ( $c f$. ibid.: p. 79). Above $1000^{\circ} \mathrm{C}$, compositions of ilm(ss) may incorporate $\mathrm{Ti}^{3+}$.

Pseudobrookite-Ferrous Pseudobrookite Solid-Solution Series, or orthorhombic oxides. The series is complete at $1150^{\circ} \mathrm{C}$ (Akimoto et al., 1957). Below $1140^{\circ} \mathrm{C}$, ferrous pseudobrookite is unstable with respect to ilm(ss) and rut(ss) (Haggerty and Lindsley, 1970; $c f$. Grey and Merritt, 1981: p. 290). The instability divides the series in two. The longer span reaches across region $\alpha$; a shorter portion, a fpb(ss) in equilibrium with metallic iron, lies in region $\beta^{5}$. The $\mathrm{fpb}(\mathrm{ss})$ in region $\beta$ remains stable down to $1068^{\circ} \mathrm{C}$, at which point it breaks down to rut(ss) and ilm(ss) (Simons and Woermann, 1978: p. 88; Grey and Merritt, 1981: p. 287, Fig. 2; Eriksson et al., 1996: Fig. 5; cf. Taylor, 1964: p. 1026; Saha and Biggar 1974: Fig. 3) $)^{6}$. Between $1068^{\circ} \mathrm{C}$ and $1140^{\circ} \mathrm{C}$, then, there are two miscibility gaps in the series (see Ender et al., 1980: Fig. 1; Eriksson et al., 1996: Fig. 2; Grey and Merritt, 1981: Fig. 3). An $M_{3} \mathrm{O}_{5}$ (ss) in equilibrium with $\mathrm{Fe}^{0}$ is found only above $1068^{\circ} \mathrm{C}$. Below $585^{\circ} \mathrm{C}$, pseudobrookite breaks down to hematite and rutile (Haggerty and Lindsley, 1970: p. 249). The orthorhombic series is the only complete one in the system: at $1346^{\circ} \mathrm{C}$, solid solution extends between $\mathrm{Fe}_{2} \mathrm{TiO}_{5}$ and $\mathrm{Ti}_{3} \mathrm{O}_{5}$ (Grey and Merritt, 1981: p. 287, Fig. 2; Grey and Ward 1973: p. 301, Fig. 3). The series is not entirely uniform in structure: as the $\mathrm{Ti}_{3} \mathrm{O}_{5}$ end-member is approached, the oxides crystallize into a monoclinic distortion of the orthorhombic structure (Pauling, 1930; Grey and Ward, 1973: pp. 302-303; Eriksson et al., 1996: p. 1840).

The monophasic fields of the other oxides in the system are less extensive. Cation-deficient wüstite lies near the $\mathrm{FeO}$ apex, being confined to region $\alpha$. Rutile lies at the $\mathrm{TiO}_{2}$ apex. It is anion-deficient at higher temperatures, lying in regions $\alpha$ and $\beta$. Between $\mathrm{TiO}_{2}$ (rutile) and $\mathrm{Ti}_{3} \mathrm{O}_{5}$ (ss) in region $\beta$ lie non-stoichiometric rutile (at higher temperatures) and two classes of ordered titanium oxide (see Den Hoed 1993: p. 192). The oxide categories are identified as:

- reduced rutile, $\mathrm{TiO}_{x}$, for $1.98 \leq x \leq 2.00$;

- higher Magnéli, or line (Reece and Morrell, 1991), phases; $\mathrm{Ti}_{n} \mathrm{O}_{2 n-1}$, for $10 \leq n \leq 30$;

\footnotetext{
5 The pattern of phase assemblages at these temperatures can be seen in Figure 3.

6 Merritt and Turnbull (1974: p. 257), for the same event, record a temperature of $1154^{\circ} \mathrm{C}$, which is inconsistent with the foregoing results: it denies the stabilization of $\mathrm{fpb}(\mathrm{ss})$ by $\mathrm{Ti}^{3+}$.
} 
- Magnéli phases, $\mathrm{Ti}_{n} \mathrm{O}_{2 n-1}$, for $4 \leq n \leq 9$ (see Den Hoed, 1993: pp. 191-192).

Lying along the top boundary in Figure 2 are the important six discrete Magnéli phases. The inclusion of ferrous ions at higher temperatures forms them into stoichiometric solid solutions, which lie parallel to the three major solid-solution series in the system.

Between the fields of single phases on the phase diagram lie the assemblages, some of two phases, others of three (these numbers refer to condensed phases only). All but one of the three-phase assemblages (indicated by stippling in Fig. 2) include metallic iron; their fields terminate at the $\mathrm{Fe}$ apex. The compositions of the phases are invariant. Twophase assemblages contain metallic iron when the oxide member lies at or near the (ferric-depleted) extremity of a solid-solution field. These fields, which alternate with the triple-phase regions in Figure 2, also terminate at the $\mathrm{Fe}$ apex. Other assemblages of two phases are exclusively oxide in composition. So, for example, on one side of the join $\mathrm{AB}$, oxide members of the $\mathrm{Fe}_{3} \mathrm{O}_{4}-\mathrm{Fe}_{2} \mathrm{TiO}_{4}$ solid-solution series (mt-usp[ss]) and the $\mathrm{Fe}_{2} \mathrm{O}_{3}-\mathrm{FeTiO}_{3}$ solid-solution series (hem-ilm[ss]) co-exist at equilibrium; on the other side of the join, an assemblage of usp(ss), ilm(ss), and $\mathrm{Fe}^{0}$ is stable (the co-ordinates at A) and B) give the compositions of the two oxides). In Figure 2, however, it is only in three-phase assemblages that the compositions of the individual phases are specified. Knowledge of the compositions of co-existing oxides in two-phase assemblages, as well as the stability of a particular composition within a solid solution, is subject to a further variable, the oxygen fugacity.

\section{OXYGEN FUGACITY}

This variable defines the potential for iron and titanium to exist in any one of several oxidation states. Some values have been superimposed on the isothermal phase diagram in Figure 2. It is invariant in certain fields. Unique values of the oxygen fugacity $\left(f_{\mathrm{O}_{2}}\right)$, in keeping with Gibbs' phase rule, suffice to stabilize each one of the three-phase assemblages (the stippled regions). Table 2 lists the oxygen fugacities of these invariant assemblages together with their oxide compositions. Oxygen isobars cross the fields of two-phase assemblages. These tie, or conjugation, lines (Taylor, 1964; Johnson et al., 1971) connect either two oxides from adjacent solid solutions or oxides with metallic iron. The condensed phases co-exist at equilibrium in the assemblage, and their compositions are located on the diagram where the isobar intersects the boundary of the solid-solution series (isobars are not drawn in on the oxide- $\mathrm{Fe}^{0}$ fields). Tie lines in the vicinity of the FeO-TiO ${ }_{2}$ join lie parallel to the join (see Den Hoed, 1993: pp. 188-190).

Values of the oxygen fugacity decrease across the phase diagram. Along the $\mathrm{Fe}_{2} \mathrm{O}_{3}-\mathrm{TiO}_{2}$ axis, where, depending on the iron-titanium ratio of the system, the equilibrium
TABLE 2

Invariant two-and three-phase assemblages in the Fe-Ti-O system at $1000^{\circ} \mathrm{C}$ and $1 \mathrm{~atm}$

\begin{tabular}{|c|c|c|c|c|c|}
\hline $\begin{array}{c}\text { Field/ } \\
\text { Join (see } \\
\text { Fig. 2) }\end{array}$ & $\begin{array}{c}\text { Assemblage } \\
\text { (with } \\
\left.\mathrm{Fe}^{0}\right) \dagger \\
\end{array}$ & $\begin{array}{c}\text { Phase } \\
\text { composition }\end{array}$ & Ref. & $\begin{array}{c}\text { Oxygen } \\
\text { fugacity } \\
(\mathrm{atm})\end{array}$ & Ref. \\
\hline $\mathrm{i}$ & $\begin{array}{c}\text { hem } \\
+ \\
\text { mt(ss) }\end{array}$ & $\begin{array}{c}\mathrm{Fe}_{2} \mathrm{O}_{3} \\
+ \\
\mathrm{Fe}_{2.987} \mathrm{O}_{4}\end{array}$ & $\begin{array}{c}- \\
\text { see text }\end{array}$ & $10^{-5.7}$ & see text \\
\hline ii & $\begin{array}{c}\text { mt } \\
+ \\
\text { wüs }\end{array}$ & $\begin{array}{c}\mathrm{Fe}_{3} \mathrm{O}_{4} \\
+ \\
\mathrm{Fe}_{0.877} \mathrm{O}\end{array}$ & $\begin{array}{c}- \\
\text { see text }\end{array}$ & $10^{-12.8}$ & see text \\
\hline iii & $\begin{array}{c}\text { wüs } \\
+ \\
\text { iron }\end{array}$ & $\begin{array}{c}\mathrm{Fe}_{0.954} \mathrm{O} \\
+ \\
\gamma \mathrm{Fe}\end{array}$ & $\begin{array}{c}\text { see text } \\
-\end{array}$ & $10^{-14.9}$ & see text \\
\hline I & $\begin{array}{l}\text { wüs(ss) } \\
+ \\
\text { usp(ss) }\end{array}$ & $\begin{array}{c}\mathrm{Fe}_{0.916} \mathrm{Ti}_{0.019} \mathrm{O} \\
+ \\
\mathrm{Fe}_{2.163} \mathrm{Ti}_{0.808} \square_{0.029} \mathrm{O}_{4} \\
\end{array}$ & a & $10^{-14.9}$ & d \\
\hline II & $\begin{array}{l}\text { usp(ss) } \\
+ \\
\text { ilm(ss) }\end{array}$ & $\begin{array}{c}\mathrm{Fe}_{1.973} \mathrm{Ti}_{0.994}{ }_{0.033} \mathrm{O}_{4} \\
+ \\
\mathrm{Fe}_{1.02} \mathrm{Ti}_{0.98} \mathrm{O}_{3}\end{array}$ & a & $10^{-15.5}$ & $\mathrm{e}$ \\
\hline IIIA & $\begin{array}{l}\text { ilm(ss) } \\
\quad+ \\
\text { rut }\end{array}$ & $\begin{array}{c}\mathrm{Fe}_{0.992} \mathrm{Ti}_{1.008} \mathrm{O}_{3} \\
+ \\
\mathrm{TiO}_{2} \text { (approx.) }\end{array}$ & a (estimated) & $10^{-16.4}$ & $\mathrm{f}$ \\
\hline IV & $\begin{array}{l}\text { ilm(ss) } \\
\quad+ \\
\text { fpb(ss) } \\
+ \\
\text { rut }\end{array}$ & $\begin{array}{c}\mathrm{Fe}_{1.043} \mathrm{Ti}_{0.957} \mathrm{O}_{3} \\
+ \\
\mathrm{Fe}_{1.219} \mathrm{Ti}_{1.781} \mathrm{O}_{5} \\
+ \\
+ \\
\mathrm{TiO}_{2} \text { (approx.) }\end{array}$ & $\begin{array}{l}\mathrm{b} \\
\mathrm{b} \\
-\end{array}$ & $10^{-10.3}$ & $\mathrm{~g}$ \\
\hline V & $\begin{array}{c}\operatorname{Mph}(n=9) \\
+ \\
\operatorname{Mph}(n=8)\end{array}$ & $\begin{array}{c}\mathrm{Ti}_{9} \mathrm{O}_{17} \\
+ \\
\mathrm{Ti}_{8} \mathrm{O}_{15} \\
\end{array}$ & $\begin{array}{l}- \\
-\end{array}$ & $10^{-19.2}$ & $\mathrm{~h}$ \\
\hline $\mathrm{X}$ & $\begin{array}{c}\text { Mph }(n=4) \\
+ \\
\text { Ans }\end{array}$ & $\begin{array}{c}\mathrm{Ti}_{4} \mathrm{O}_{7} \\
+ \\
\mathrm{Ti}_{3} \mathrm{O}_{5}\end{array}$ & $\begin{array}{l}- \\
\mathrm{c}\end{array}$ & $10^{-20.6}$ & $\mathrm{i}$ \\
\hline
\end{tabular}

$\dagger \mathrm{Fe}^{0}$ is absent from assemblages $\mathrm{i}$, ii, IV and $\mathrm{V}$.

a Simons and Woermann (1978: Tab.3).

b Haggerty and Lindsley (1970: Fig. 28).

c Grey and Merritt (1981: Fig. 3).

d Simons and Woermann (1978: Tab. 2); cf. Borowiec and Rosenqvist (1981: p. 220)

e Borowiec and Rosenqvist (1981: p. 220); see also Taylor and Schmalzried (1964:

Tab. 1); Shchepëtkin et al. (1968); Merritt and Turnbull (1974: Fig. 2); Simons and

Woermann (1978: Tab. 2); Anovitz et al. (1985: Fig. 3); O’Neill et al. (1988:

p. 2070).

f Borowiec and Rosenqvist (1981: Tab. 2); see also Taylor and Schmalzried (1964:

Tab. 1); Shchepëtkin et al. (1968); Fetisov et al. (1969); Merritt and Turnbull (1974:

Fig. 2); Borowiec and Rosenqvist (1985: Fig. 5; 1981: p. 220); Anovitz et al. (1985:

Fig. 2); O'Neill et al. (1988: p. 2069).

g Borowiec and Rozenqvist (1985: Fig. 5).

h From data in Merritt et al. (1973: Tab. 5) and Suzuki and Sambongi (1972, as cited in Grey et al. (1974b: Tab. 3, Fig. 3)), assuming that $\log p_{\mathrm{O}}$ changes linearly with

1/T (cf. Bartholomew and White 1970: Fig. 1, citing Porter (1965)).

i Borowiec and Rosenqvist (1985: Fig. 5; 1981: p. 220).

assemblages are either hematite and pseudobrookite, or rutile and pseudobrookite, $f_{\mathrm{O}_{2}}$ is $0.21 \mathrm{~atm}$. Phases contain less ferric ion with decreasing fugacity. Metallic iron is stabilized below 10-14.9 atm (O’Neill, 1988: p. 477). 


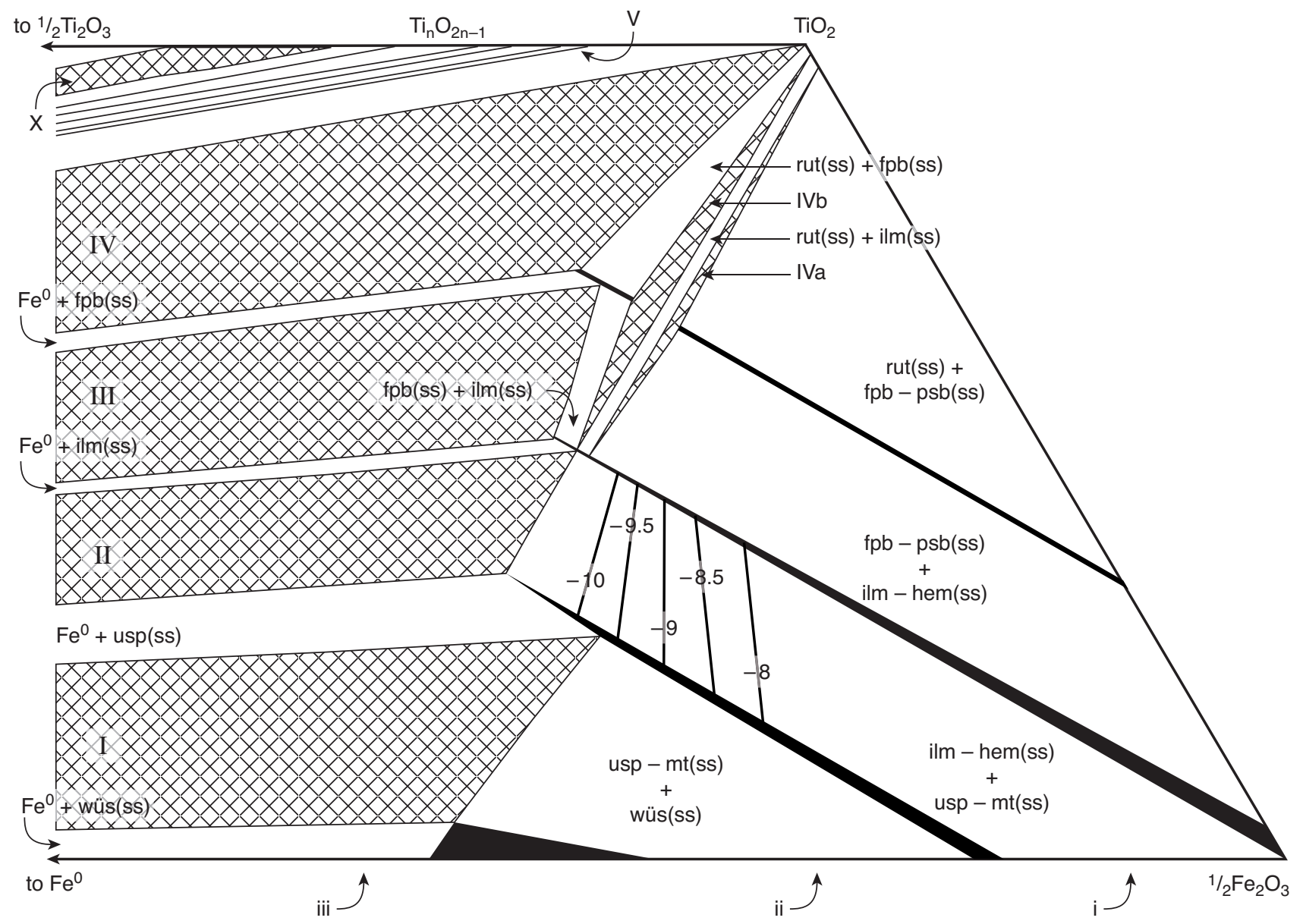

Figure 3

Phase relations in the system $\mathrm{Fe}-\mathrm{Fe}_{2} \mathrm{O}_{3}-\mathrm{TiO}_{2}-\mathrm{Ti}_{3} \mathrm{O}_{5}$ at $1130^{\circ} \mathrm{C}$ (molar basis). The phase diagram captures the two miscibility gaps in the orthorhombic series between $1068^{\circ} \mathrm{C}$, at which $\mathrm{fpb}(\mathrm{ss})$ is stabilized, and $1140^{\circ} \mathrm{C}$, at which assemblages IVa and IVb disappear. Compositions of rut(ss) and ilm(ss) in regions $\mathrm{IVa}$ and $\mathrm{IVb}$ are estimated. The miscibility gap in psb-fpb(ss) extends from $\mathrm{Fe}_{1.05} \mathrm{Ti}_{1.95} \mathrm{O}_{5}$ to $\mathrm{Fe}_{0.96} \mathrm{Ti}_{2.04} \mathrm{O}_{5}$ (Grey and Merritt, 1981: Fig. 3).

A change in alignment of oxygen isobars presages a miscibility gap in solid-solution series, as in the $\mathrm{Fe}_{2} \mathrm{O}_{3^{-}}$ $\mathrm{FeTiO}_{3}(\mathrm{ss})$ at $1200^{\circ} \mathrm{C}$, where the isobars between $10^{-4}$ and $10^{-3} \mathrm{~atm}$ are seen to open out in the phase diagram (see Den Hoed, 1993: Fig. 6). At these pressures, a large change in composition accompanies a small change in $f_{\mathrm{O}_{2}}$ (Webster and Bright, 1961: Fig. 1). The solid-solution series, moreover, loses its non-stoichiometry as the consolute temperature is approached. While the phase itself persists, the range of its compositions is narrowed.

Chemical composition, alongside oxygen fugacity and phase types, completes the set of variables in the system. Like the other variables, it is measured in synthesis studies.

\section{COMPOSITION}

Three-phase assemblages form, as shown in the phase diagram, at low oxygen fugacities. Conditions for their stability are invariant. Table 2 lists, along with the oxygen fugacity, the chemical composition of each phase in four of these assemblages. We present here information relating to other parts of the system.

\section{4. $1 \mathrm{Fe}^{-} \mathrm{Fe}_{2} \mathrm{O}_{3}$ Binary}

Darken and Gurry $(1945,1946)$ produced the seminal study of this system. The phase diagram for this binary (on composition-temperature co-ordinates) was constructed from these 
and other sources. The diagram is also extensively published (see, for example, Muan, 1970: Fig. 3; Levin and McMurdie, 1975: Fig. 4155; Lindsley, 1976b: Fig. L21, 1991: Fig. 1; Kowalski et al., 1995: Fig. 3.5-3.7). From $560^{\circ} \mathrm{C}$ to the solidus, three oxides - magnetite, hematite, and wüstite are present.

\section{2 $\mathrm{Ti}_{3} \mathrm{O}_{5}-\mathrm{TiO}_{2}$ Binary}

De Vries and Roy (1954) compiled the first crude phase diagram of the system $\mathrm{Ti}_{-} \mathrm{TiO}_{2}$, a map of the compositional extents of phases at liquidus and sub-solidus temperatures, which Wahlbeck and Gilles (1966) subsequently modified with data published in the intervening years. The interval $\mathrm{Ti}_{3} \mathrm{O}_{5}$ to $\mathrm{TiO}_{2}$ is relevant in illmenite smelting. Later studies were to attain better resolutions and to measure oxygen potentials (see Porter, 1965; Zador, 1968; Suzuki and Sambongi, 1972; Merritt et al., 1973; Grey et al., 1974b; Kowalski et al., 1995: Fig. 3.14).

\subsection{Magnéli Phases}

$\mathrm{Fe}^{2+}$ is one of several species to be present in these oxides at higher temperatures $\left(>1000^{\circ} \mathrm{C}\right)$. Its inclusion leads to a series of short, parallel solid-solution series, certain members of which are in equilibrium with metallic iron at high temperatures. Grey et al. (1974b) measured the compositions of three-phase assemblages in this part of the system at $1200^{\circ} \mathrm{C}$, and the invariant oxygen fugacities stabilizing them (see Den Hoed, 1993: pp. 152-153).

\section{THE Fe-Ti-O SYSTEM AT $1130^{\circ} \mathrm{C}$}

Although there are more data of phase equilibria in the $\mathrm{Fe}-\mathrm{Fe}_{2} \mathrm{O}_{3}-\mathrm{TiO}_{2}-\mathrm{Ti}_{2} \mathrm{O}_{3}$ system at $1200^{\circ} \mathrm{C}$ than at any other temperature, enough work has been done to construct the phase diagrams for the system at $1130^{\circ} \mathrm{C}$ (see Simons and Woermann, 1978: Fig. 1). The first significant measurements were the compositions and fugacities at which the phases wüs(ss), usp(ss), ilm(ss), fpb(ss), and $\operatorname{rrt}(\mathrm{ss})$ co-exist with metallic iron. Details of the Magnéli phases in equilibrium with $\mathrm{Fe}^{0}$ at $1000^{\circ} \mathrm{C}$ remain unmeasured. The oxygen isobars crossing the $\mathrm{FeO}-\mathrm{Fe}_{2} \mathrm{O}_{3}-\mathrm{TiO}_{2}$ space were recorded at $1300^{\circ} \mathrm{C}$ (Taylor, 1964); those for co-existing spinel and rhombohedral solid solutions were derived by Spencer and Lindsley (1981). Illustrated here, then, is the three phase diagram for the system at $1130^{\circ} \mathrm{C}$ (see Fig. 3). The invariant conditions in the system are summarized in Table 3.

There are isothermal phase diagrams at other temperatures. Taylor (1963) published the liquidus surface for the system; Lindsley (1991: Fig. 8) and Gupta et al. (1989a) furnish diagrams at temperatures below $1000^{\circ} \mathrm{C}$. The two temperatures presented here, however, adequately portray the phases,
TABLE 3

Invariant two-and three-phase assemblages in the Fe-Ti-O system at $1130^{\circ} \mathrm{C}$ and $1 \mathrm{~atm}$

\begin{tabular}{|c|c|c|c|c|c|}
\hline $\begin{array}{c}\text { Field/ } \\
\text { Join (see } \\
\text { Fig. 3) }\end{array}$ & $\begin{array}{c}\text { Assemblage } \\
\text { (with } \\
\left.\mathrm{Fe}^{0}\right) \dagger\end{array}$ & $\begin{array}{c}\text { Phase } \\
\text { composition }\end{array}$ & Ref. & $\begin{array}{c}\text { Oxygen } \\
\text { fugacity } \\
\text { (atm) }\end{array}$ & Ref. \\
\hline $\mathrm{i}$ & $\begin{array}{c}\text { hem } \\
+ \\
\text { mt(ss) }\end{array}$ & $\begin{array}{c}\mathrm{Fe}_{2} \mathrm{O}_{3} \\
+ \\
\mathrm{Fe}_{2.969} \mathrm{O}_{4}\end{array}$ & $\begin{array}{c}- \\
\text { see text }\end{array}$ & $10^{-4.2}$ & see text \\
\hline ii & $\begin{array}{c}\text { mt } \\
+ \\
\text { wüs }\end{array}$ & $\begin{array}{c}\mathrm{Fe}_{3} \mathrm{O}_{4} \\
+ \\
\mathrm{Fe}_{0.865} \mathrm{O}\end{array}$ & $\begin{array}{c}- \\
\text { see text }\end{array}$ & $10^{-10.3}$ & see text \\
\hline iii & $\begin{array}{c}\text { wüs } \\
+ \\
\text { iron }\end{array}$ & $\begin{array}{c}\mathrm{Fe}_{0.954} \mathrm{O} \\
+ \\
\gamma \mathrm{Fe}\end{array}$ & $\begin{array}{c}\text { see text } \\
-\end{array}$ & $10^{-12.9}$ & see text \\
\hline I & $\begin{array}{c}\text { wüs } \\
+ \\
\text { usp(ss) }\end{array}$ & $\begin{array}{c}\mathrm{Fe}_{0.880} \mathrm{Ti}_{0.037} \mathrm{O} \\
+ \\
\mathrm{Fe}_{2.17} \mathrm{Ti}_{0.81} \square_{0.02} \mathrm{O}_{4}\end{array}$ & $\mathrm{a}$ & $10^{-12.8}$ & $\mathrm{c}$ \\
\hline II & $\begin{array}{c}\text { usp(ss) } \\
+ \\
\text { ilm(ss) }\end{array}$ & $\begin{array}{c}\mathrm{Fe}_{1.944} \mathrm{Ti}_{1.024}{ }_{0.032} \mathrm{O}_{4} \\
+ \\
\mathrm{Fe}_{1.003} \mathrm{Ti}_{0.998} \mathrm{O}_{3}\end{array}$ & $\mathrm{a}$ & $10^{-13.6}$ & d \\
\hline III & $\begin{array}{c}\mathrm{ilm}(\mathrm{ss}) \\
+ \\
\mathrm{fpb}(\mathrm{ss})\end{array}$ & $\begin{array}{c}\mathrm{Fe}_{0.974} \mathrm{Ti}_{1.026} \mathrm{O}_{3} \\
+ \\
\mathrm{Fe}_{0.896} \mathrm{Ti}_{2.104} \mathrm{O}_{5} \\
\end{array}$ & $\mathrm{a}$ & $10^{-14.1}$ & $\mathrm{e}$ \\
\hline IV & $\begin{array}{l}\mathrm{fpb}(\mathrm{ss}) \\
+ \\
\mathrm{rrt} \\
\end{array}$ & $\begin{array}{c}\mathrm{Fe}_{0.81} \mathrm{Ti}_{2.19} \mathrm{O}_{5} \\
+ \\
\mathrm{TiO}_{1.984}\end{array}$ & $\begin{array}{l}\mathrm{j} \\
\mathrm{j} \\
\end{array}$ & $10^{-14.3}$ & $\mathrm{f}$ \\
\hline IVa & $\begin{array}{l}\text { ilm(ss) } \\
+ \\
\operatorname{rut}(\mathrm{ss}) \\
+ \\
\mathrm{fpb}(\mathrm{ss})\end{array}$ & $\begin{array}{c}- \\
- \\
\mathrm{Fe}_{1.05} \mathrm{Ti}_{1.95} \mathrm{O}_{5}\end{array}$ & $\begin{array}{l}- \\
\mathrm{b}\end{array}$ & $10^{-10.8}$ & $\mathrm{~g}$ \\
\hline $\mathrm{IVb}$ & \multicolumn{2}{|c|}{$\mathrm{ilm}(\mathrm{ss})+\mathrm{fpb}(\mathrm{ss})+\operatorname{rut}(\mathrm{ss})$} & - & $10^{-12.2}$ & $\mathrm{~h}$ \\
\hline $\mathrm{V}$ & $\begin{array}{c}\operatorname{Mph}(n=9) \\
+ \\
\operatorname{Mph}(n=8)\end{array}$ & $\begin{array}{c}\mathrm{Ti}_{9} \mathrm{O}_{17} \\
+ \\
\mathrm{Ti}_{8} \mathrm{O}_{15} \\
\end{array}$ & $\begin{array}{l}- \\
- \\
\end{array}$ & $10^{-16.2}$ & $\mathrm{i}$ \\
\hline$X$ & $\begin{array}{c}\text { Mph }(n=4) \\
+ \\
\text { Ans }\end{array}$ & $\begin{array}{c}\mathrm{Ti}_{4} \mathrm{O}_{7} \\
+ \\
\mathrm{Ti}_{3} \mathrm{O}_{5}\end{array}$ & $\begin{array}{l}- \\
\mathrm{b}\end{array}$ & $10^{-17.9}$ & $\mathrm{~g}$ \\
\hline
\end{tabular}

$\dagger \mathrm{Fe}^{0}$ is absent from assemblages ii, IVa, IVb and $\mathrm{V}$.

a Simons and Woermann (1978: Tab. 3).

b Grey and Merritt (1981: Fig. 3); cf. Ender et al. (1980: Fig. 1).

c Simons and Woermann (1978: Tab. 2); cf. Borowiec and Rosenqvist (1981: p. 220).

d O'Neill et al. (1988: p. 2070); Borowiec and Rosenqvist (1981: p. 220); Merritt and Turnbull (1974: Fig. 2); see also Taylor and Schmalzried (1964: Tab. 1); Simons and Woermann (1978: Tab. 2); Anovitz et al. (1985: Fig. 3).

e Simons and Woermann (1978: Tab. 2); see also Taylor and Schmalzried (1964:

Tab. 1); Merritt and Turnbull (1974: Fig. 2); Grey and Merritt (1981: Fig. 2);

Borowiec and Rosenqvist (1985: Fig. 5).

f Simons and Woermann (1978: Tab. 2); Grey and Merritt (1981: Fig. 2); Borowiec and Rosenqvist (1985: Fig. 5).

g Borowiec and Rozenqvist (1985: Fig. 5)

h Grey and Merritt (1981: Fig. 2); cf. Borowiec and Rozenqvist (1985: Fig. 5).

i From data in Merritt et al. (1973: Tab. 5) and Suzuki and Sambongi (1972, as cited in Grey et al. (1974b: Tab. 3, Fig. 3)), assuming that $\log p_{\mathrm{O}}$ changes linearly with 1/T (cf. Bartholomew and White, 1970: Fig. 1, citing $\operatorname{Porter}^{2}(1965)$ ).

j Woermann, pers. comm. 
compositions, and oxygen fugacities encountered in the solid-state reduction and oxidation of ilmenite in chemical looping combustion and gasification. The phase diagram at $1000^{\circ} \mathrm{C}$ is more relevant than the one at $1130^{\circ} \mathrm{C}$, which serves merely to illustrate the extent to which the phase relations change over $130^{\circ} \mathrm{C}$. One can see, for example, how the orthorhombic solid-solution series changes with temperature; it displays a single miscibility gap above $1140^{\circ} \mathrm{C}$ (closing at $1346^{\circ} \mathrm{C}$ ) and below $1068^{\circ} \mathrm{C}$, and two gaps in the interval (Grey and Merritt, 1981: Fig. 3). An invariant point exists in this region of the system at $1068^{\circ} \mathrm{C}$ : an assemblage of four phases $-\mathrm{Fe}^{0}, M_{3} \mathrm{O}_{5}(\mathrm{ss}), M_{2} \mathrm{O}_{3}(\mathrm{ss})$, and rut - is stable at 10-15.5 atm (Borowiec and Rosenqvist, 1985: pp. 35-36). Trends in the oxygen fugacity are evident, too. Increasing temperature forces a given three-phase assemblage (with $\mathrm{Fe}^{0}$ ) to be stable at higher fugacities, while a given tie line $\left(f_{\mathrm{O}_{2}}\right)$ in any two-phase field shifts away from the $\mathrm{Fe}_{2} \mathrm{O}_{3}$ apex towards the $\mathrm{Ti}_{2} \mathrm{O}_{3}$ apex.

We would add a rider to the application of these phase diagrams in the reduction and oxidation of natural ilmenite. Manganese and magnesium are significant components in Australian and South African ilmenites collected from placer deposits. Ilmenite processed at one time by Western Titanium (in Australia) contained $1.6 \mathrm{~mol} \% \mathrm{MnO}$ (Grey and Reid, 1974: p. C41); ilmenite from the east coast had similar amounts of both $\mathrm{MnO}$ and $\mathrm{MgO}$, the one or other species being present in any grain of ilmenite (Jones, 1973: Tab. 2; 1974: p. C2). The ilmenite upgraded by Richards Bay Minerals (RBM) contains $1.1 \mathrm{~mol} \% \mathrm{MnO}$ and $0.7 \mathrm{~mol} \%$ $\mathrm{MgO}$ (see Den Hoed, 1993: pp.33-36). Norwegian ilmenites, too, include these impurities; concentrates mined from the Tellnes deposit contain 4.6 wt\% $\mathrm{MgO}$ (Borowiec and Rosenqvist, 1985: p. 33). It is the presence of these two components in natural ilmenites that Grey et al. (1974a) were to identify, by the application of (quaternary) phase diagrams in the system Fe-(Mg,Mn)-Ti-O, as stabilizing the orthorhombic $M_{3} \mathrm{O}_{5}$ (ss) phase during reduction. Moving to the quaternary system will be useful should the phases formed during reduction and oxidation in chemical looping processes deviate from assemblages predicted by the system Fe-Ti-O.

\section{ISOTHERMAL REVERSIBLE REDUCTION AND OXIDATION}

Reduction and oxidation are represented on the isothermal phase diagrams by a straight line, called the oxygen-reaction line (Taylor, 1964: p. 1017), set at a constant Fe-Ti ratio. The line passes through the oxygen co-ordinate, which is defined on the Fe-Ti-O diagram by an apex, and on the $\mathrm{FeO}-\mathrm{Fe}_{2} \mathrm{O}_{3}$ $\mathrm{TiO}_{2}-\mathrm{Ti}_{2} \mathrm{O}_{3}$ diagram by a point off to infinity at the right (Fig. 2, 3). It plots the path of phase formations as oxygen is added to or removed from the system under reversible conditions (that is, never more than infinitesimally displaced from equilibrium). This path may be followed for an hypothetical ilmenite with an $\mathrm{Fe} /[\mathrm{Fe}+\mathrm{Ti}]$ molar ratio of 0.5 (see Fig. 4). Consider oxidation first. Several studies have argued that, if sintering is to be prevented, ilmenite should be subjected to oxidation as a first step before reduction (see, for example, Pröll et al., 2009). Starting with ilm(ss) at $1000^{\circ} \mathrm{C}$, then, the system undergoes a sequence of transformations with increasing oxygen fugacity, represented by line PQ in Figure 4 (cf. Grey et al., 1974a: p. C108):

- $\mathrm{TiO}_{2}$ (rutile) appears first as $\mathrm{Fe}^{2+}$ in the ilm(ss) oxidizes to $\mathrm{Fe}^{3+}$

- at $10^{-10.3} \mathrm{~atm}\left(p_{\mathrm{O}_{2}}\right)$, the equilibrium assemblage is ilm(ss) $+\mathrm{fpb}(\mathrm{ss})+\operatorname{rut}(\mathrm{see} T a b .2)$;

- at higher oxygen partial pressures assemblages of two phases - ilm(ss) + fpb(ss) - are stabilized;

- at still higher $p_{\mathrm{O}_{2}}$, the two-phase assemblage gives way to a single phase, a solid solution, fpb(ss), denoted by P' (see Fig. 4);

- in the final increase in $p_{\mathrm{O}_{2}}$ to $0.21 \mathrm{~atm}$ (that of air), the phase assemblage is two phase once more, rut $+\mathrm{psb}(\mathrm{ss})$, with the $\mathrm{Fe}^{2+} / \mathrm{Fe}^{3+}$ ratio in the $\mathrm{psb}$ (ss) dropping to zero. At equilibrium in air at $1000^{\circ} \mathrm{C}, \mathrm{TiO}_{2}$ (rutile) co-exists with $\mathrm{Fe}_{2} \mathrm{TiO}_{5}$ (pseudobrookite) in the ratio $50 \mathrm{~mol} \%$ $\mathrm{TiO}_{2} / 50 \mathrm{~mol} \% \mathrm{Fe}_{2} \mathrm{TiO}_{5}$.

When reduction follows oxidation, the oxygen partial pressure drops. Under reversible conditions the system will "retrace" its steps, its phase-chemical composition moving from Q back to P (see Fig. 4). When the oxygen partial pressure reaches $10^{-16.4}$ metallic iron forms (field IIIA, Fig. 4, $T a b .2$ ). The system holds this $p_{\mathrm{O}_{2}}$ as ilm(ss) is converted to rut and $\mathrm{Fe}^{0}$. At still lower $p_{\mathrm{O}_{2}}$, the Magneli phases are stabilized along with metallic iron. In chemical looping combustion, however, this is a condition to be avoided, as subsequent reduction and oxidation destroys the integrity of particles (see Den Hoed and Luckos, 2010). A reason for this discouraging development is hinted at in the phase diagram. Beyond point $\mathrm{P}$ lies a three-phase assemblage. Two of the phases in that assemblage $-\mathrm{Fe}^{0}$ and ilm(ss) - can undergo re-oxidation. In the air reactor of a chemical looping process there is, in practice, insufficient time for the phases to re-equilibrate during oxidation (see Eriksson et al., 1996: p. 1840, who describe equilibrating samples for 42 hours at $1100^{\circ} \mathrm{C}$ ). Thus, one is unlikely to see the assemblage $\mathrm{Fe}^{0}+\mathrm{Fe}_{0.992} \mathrm{Ti}_{1.008} \mathrm{O}_{3}+$ $\mathrm{TiO}_{2}$ (field IIIA in Fig. 4) reforming as ilm(ss) + rut when the oxygen partial pressure rises above $10^{-16.4}$. Instead, one is more likely to see metallic iron follow its own reaction line along the base of the phase diagram: as the partial pressure rises, so $\mathrm{Fe}^{0}$ oxidizes to $\mathrm{F}_{0.954} \mathrm{O}$ (wüstite), which in turn oxidizes to the end-member $\mathrm{F}_{0.877} \mathrm{O}$ (wüstite), before oxidizing further to $\mathrm{Fe}_{3} \mathrm{O}_{4}$ (magnetite). $\mathrm{Fe}_{2} \mathrm{O}_{3}$ (hematite) is stable in air at $1000^{\circ} \mathrm{C}$.

So, too, the system at $\mathrm{Q}$, under reduction, is unlikely to have sufficient time to equilibrate as it retraces its steps along $\mathrm{QP}$ (Fig. 4). $\mathrm{TiO}_{2}$ (rutile) and $\mathrm{Fe}_{2} \mathrm{TiO}_{5}$ (pseudobrookite) 


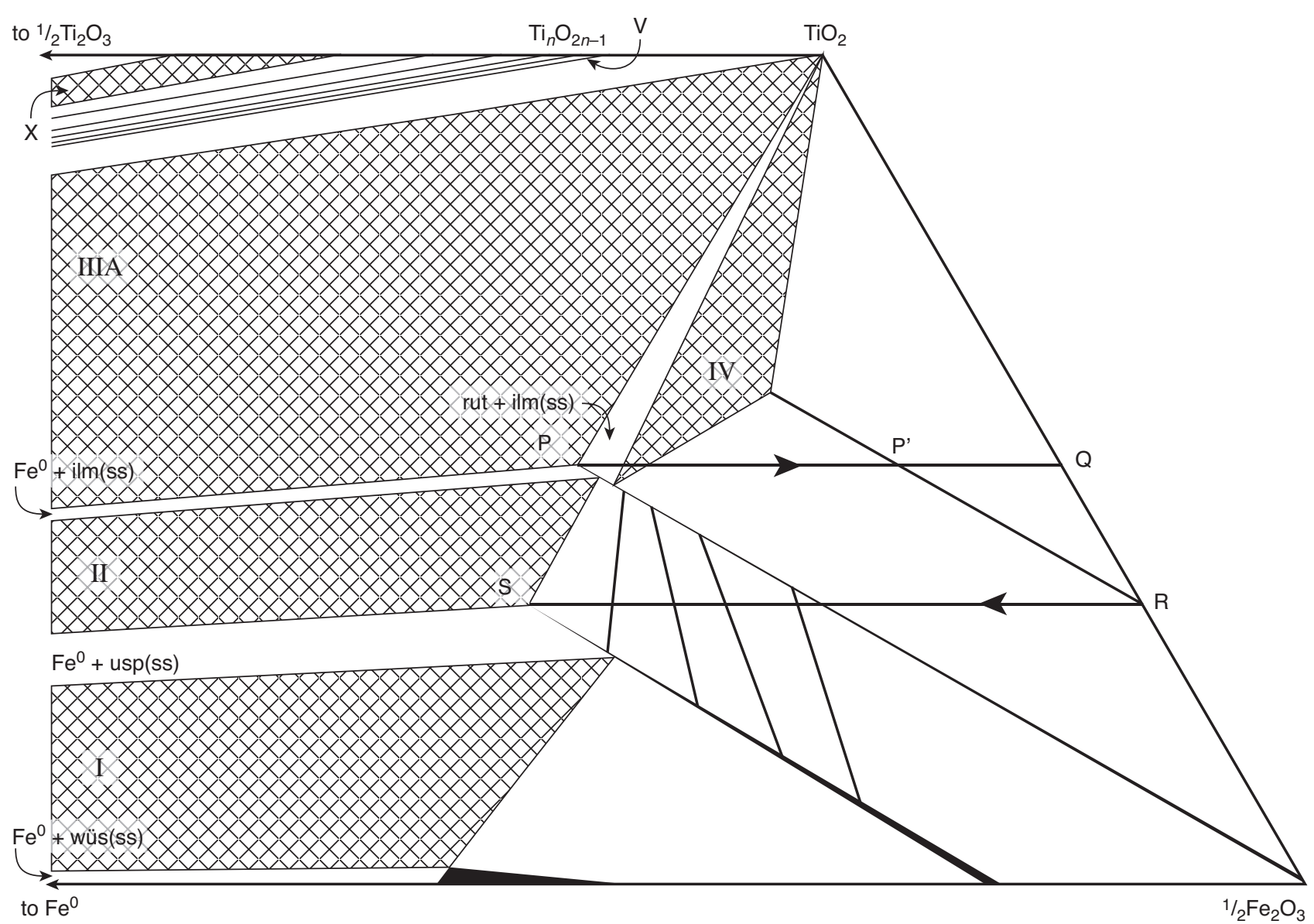

Figure 4

Phase relations and oxygen-reaction lines in the system $\mathrm{Fe}-\mathrm{Fe}_{2} \mathrm{O}_{3}-\mathrm{TiO}_{2}-\mathrm{Ti}_{3} \mathrm{O}_{5}$ at $1000^{\circ} \mathrm{C}$ (molar basis). Figure 2 provides more detail. Table 2 lists oxygen fugacities and oxide compositions of the invariant assemblages I to $\mathrm{X}$ and $\mathrm{i}$, ii and iii.

co-exist at $\mathrm{Q}$. $\mathrm{TiO}_{2}$, as a distinct phase, will remain inactive. $\mathrm{Fe}_{2} \mathrm{TiO}_{5}$ (pseudobrookite) - in effect our system - will, therefore, follow the oxygen reaction line RS (see Fig. 4):

- hem(ss) appears first, along with psb(ss);

- as $p_{\mathrm{O}_{2}}$ drops, so the $\mathrm{Fe}^{2+} / \mathrm{Fe}^{3+}$ ratio increases in psb(ss) and hem(ss), and the ratio of psb(ss) to hem(ss) shifts towards the latter;

- at just over $10^{-9} \mathrm{~atm}\left(p_{\mathrm{O}_{2}}\right)$ a single phase, ilm(ss), is stable (the hem[ss] having moved towards ilm[ss]);

- at $10^{-15.5} \leq p_{\mathrm{O}_{2}}<10^{-9} \mathrm{~atm}$, ilm(ss) is in equilibrium with usp(ss);

- at $\mathrm{S}$ (Fig. 4), a single phase, usp(ss), is stable at $p_{\mathrm{O}_{2}}=$ $10^{-15.5} \mathrm{~atm}$ (see Tab. 2).

The assemblage at $\mathrm{S}$ is a desirable end-point for reduction. Further reduction - i.e., a drop in oxygen partial pressure below $10^{-15.5} \mathrm{~atm}$ - stabilizes metallic iron, which is an unfavourable outcome for chemical looping combustion.
As we have demonstrated in our examination of phase equilibria, oxygen partial pressure, being the driving force in reduction and oxidation, plays a critical part in determining what the final assemblage of phases will be. It is controlled by the nature of the reducing agent introduced into the system. (Oxidation is usually carried out in air, or air diluted with nitrogen.) We turn to consider reducing agents and gas-phase compositions in relation to equilibrium phase assemblages predicted by phase diagrams.

\section{A DRIVING FORCE IMPOSED}

Table 4 lists the compositions of gas phases recorded in fuel-reactor tests published in the literature. To relate them to the phase diagram at $1000^{\circ} \mathrm{C}$, we have calculated the oxygen partial pressure associated with each composition. Note that the $p_{\mathrm{O}_{2}}$ of pure carbon, established by the Boudouard reaction 
TABLE 4

Published gas compositions in fuel-reactor tests

\begin{tabular}{c|c|c|c|c|c|c|c|c}
\hline & \multicolumn{7}{|c}{ Mixtures (vol\%) } \\
\cline { 2 - 9 } & $(1)$ & $(2)$ & $(3)$ & $(4)$ & $(5)$ & $(6)$ & $(7)$ & $(8)$ \\
\hline $\mathrm{H}_{2}$ & - & - & - & - & 15 & - & - & - \\
$\mathrm{H}_{2} \mathrm{O}$ & - & 50 & 20 & 47.5 & 20 & - & 79 & - \\
$\mathrm{CO}$ & - & 50 & - & 47.5 & - & 15 & 3 & - \\
$\mathrm{CO}_{2}$ & - & - & - & - & - & 20 & 17 & - \\
$\mathrm{CH}_{4}$ & 95 & - & 15 & - & - & - & 1 & - \\
$\mathrm{N}_{2}$ & - & - & 65 & - & 65 & 65 & - & 95 \\
$\mathrm{O}_{2}$ & 5 & - & - & 5 & - & - & - & 5 \\
\hline $\log p_{\mathrm{O}_{2}} \dagger$ & -27.5 & -18.7 & -16.6 & -16.2 & -14.3 & -13.7 & -12.2 & -1.3 \\
\hline
\end{tabular}

(1) Leion et al. (2009).

(2) Jerndal et al., in prep.

(3) Adánez et al. (2010).

(4) Leion et al. (2009).

(5) Adánez et al. (2010).

(6) Adánez et al. (2010).

(7) Berguerand and Lyngfelt (2008a)

(8) Leion et al. (2009).

$\dagger$ Oxygen partial pressure, expressed as a common logarithm, at $1000^{\circ} \mathrm{C}$.

$\left(\mathrm{C}_{\text {solid }}+\mathrm{CO}_{2}=2 \mathrm{CO}\right)$, is $10^{-18.4} \mathrm{~atm}$. The $p_{\mathrm{O}_{2}}$ of air is $10^{-0.68}$ atm; that of the exhaust from the air reactor $\left(5 \% \mathrm{O}_{2}\right)$ is $10^{-1.30}$ $\mathrm{atm}$. The first four compositions in Table 4 (i.e., mixtures 1-4) lie within phase fields for which metallic iron is a stable phase (see Fig. 2). At equilibrium, mixtures 5-6 will stabilize assemblages of ilm(ss) and usp(ss), close to the join $\mathrm{AB}$ (Fig. 2). (Fig. 5 relates these oxygen potentials to gas-phase compositions, one of CO- $\mathrm{CO}_{2}$, the other of $\mathrm{H}_{2}-\mathrm{H}_{2} \mathrm{O}$. For the system at equilibrium one would want the oxygen potential of the gas phase to lie close to, but above line II.) Although none of the reported studies gives clear indications of the progression of phase formations, the evidence of electron microscopy points to the absence of metallic iron or its oxidation products. The phases observed are broadly in agreement with those predicted by the phase diagram, but it appears that at no point did metallic iron form from an irontitanium oxide such as $\mathrm{Fe}_{2} \mathrm{TiO}_{5}$ (pseudobrookite). The explanation for this discrepancy may lie in kinetics: the reduction reaction in tests for which $p_{\mathrm{O}_{2}}<10^{-15.5}$ atm is given insufficient time to reach equilibrium. This explanation will remain conjecture until we identify the phases that form during reduction and oxidation and establish their changing morphologies during these processes.

What, if anything, do the phase diagrams tell us about one of the measures of the effectiveness of an oxygen carrier, that of the oxygen transport capacity, $R_{\mathrm{O}}$ ? The measure is defined as:

$$
R_{\mathrm{O}}=\frac{m_{o x}-m_{r e d}}{m_{o x}}
$$

where $m_{o x}$ is the mass of a carrier in its oxidized state and $m_{\text {red }}$ is its mass in the reduced state. Let us assume a starting point of $100 \mathrm{~g}$ of $\mathrm{FeTiO}_{3}$ (ilmenite). If a chemical looping process were to see the oxygen carrier move between states defined by the line PQ in Figure 4, then full oxidation would produce $78.94 \mathrm{~g} \mathrm{Fe}_{2} \mathrm{TiO}_{5}$ (pseudobrookite) and $26.33 \mathrm{~g} \mathrm{TiO}_{2}$ (rutile). The total mass of the oxygen carrier when fully oxidized, $m_{o x}$, would equal $105.27 \mathrm{~g}$. Under these conditions (between $\mathrm{P}$ and $\mathrm{Q}$ ) the oxygen transport capacity, $R_{\mathrm{O}}$, equals $5.0 \%$. Now consider what happens if the oxygen carrier were to move between $\mathrm{R}$ and $\mathrm{S}$ (Fig. 4) - the system, in other words, is not allowed to equilibrate. $\mathrm{TiO}_{2}$ (rutile) remains an inactive component in the oxygen carrier. The $78.94 \mathrm{~g}$ $\mathrm{Fe}_{2} \mathrm{TiO}_{5}$ (pseudobrookite) reduce to $73.67 \mathrm{~g} \mathrm{Fe}_{2} \mathrm{TiO}_{4}$ (ulvöspinel). The mass of reduced carrier is now $73.67 \mathrm{~g}$ $+26.33 \mathrm{~g}=100 \mathrm{~g}$, and the oxygen transport capacity remains $5 \%$. That the system may not equilibrate, in other words, does not lower the oxygen transport capacity of the oxygen carrier. The segregation of phases, however, may affect the long-term stability of oxygen carriers derived from ilmenite, a possibility that warrants further investigation.

\section{ACKNOWLEDGMENTS}

Much of the groundwork for this paper was laid during postgraduate studies at the University of Natal, Durban, in the 1980s (Den Hoed, 1993). MINTEK (Randburg, South Africa) sponsored the initial research. Our thanks go to Professor Johan de Villiers (University of Pretoria) and Dr Johan Nell (Hatch Africa) for discussions on the topic while the paper was in draft. One of us $(\mathrm{PdH})$ presented a shortened version of the paper at the First International Conference on Chemical Looping in Lyon on 17-19 March 2010. 


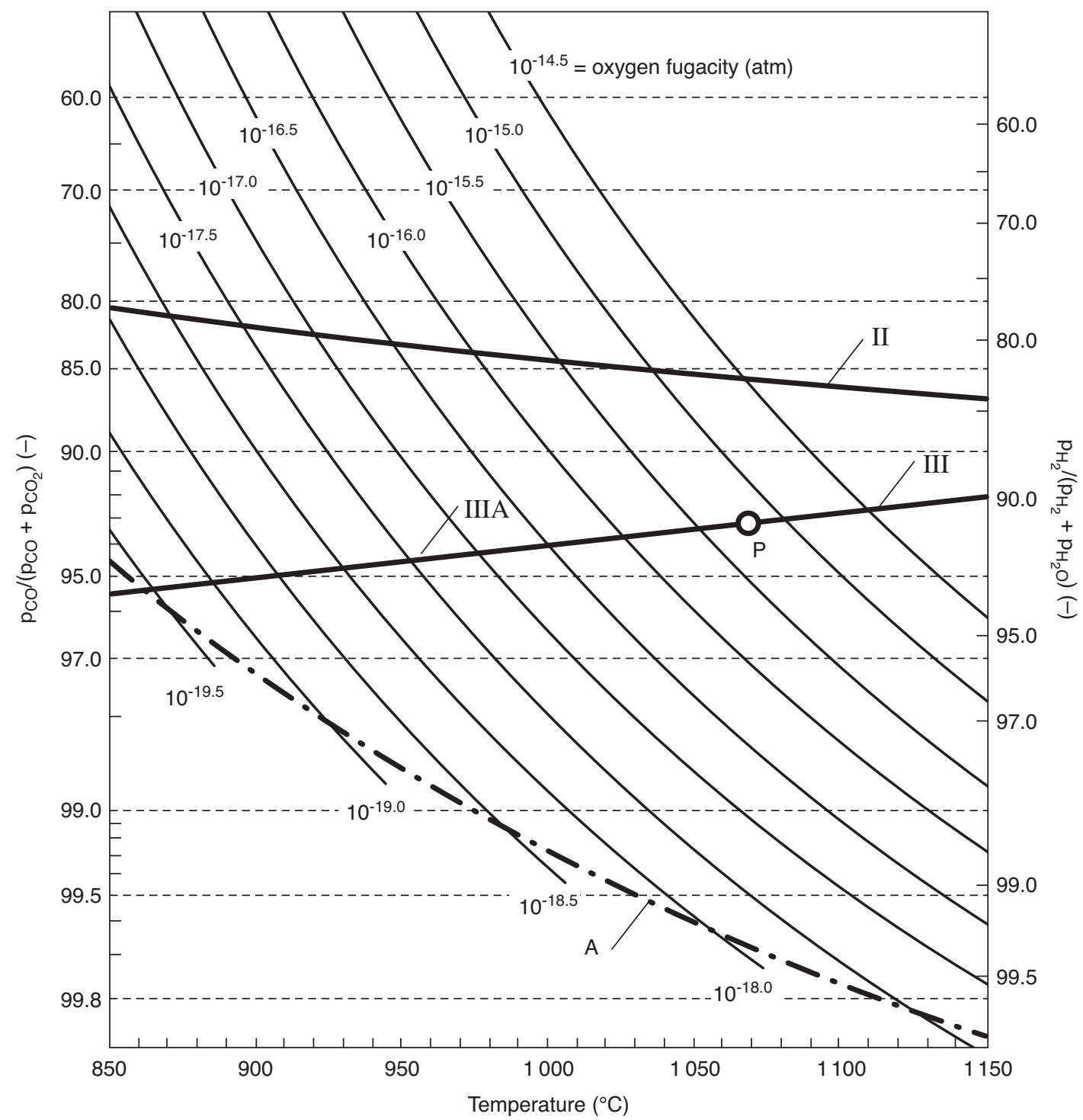

Figure 5

Equilibrium three-phase assemblages in the Fe-Ti-O system inscribed on oxygen-potential coordinates. The two $y$-axes mark the proportions of gases mixed. Curve A represents the Boudouard-reaction equilibrium at unit pressure. Curve $\mathrm{A}$ and the $f_{\mathrm{O}_{2}}$ isobars are derived from Deines et al. (1974), who used the thermochemical data listed in the JANAF tables of 1965 and 1971. The other two curves (II and III-IIIA) represent particular reaction (phase) equilibria:

II: $\quad$ usp(ss) $=\mathrm{ilm}(\mathrm{ss})+\mathrm{Fe}^{0}+\mathrm{O}_{2}$ (from data in Merritt and Turnbull, 1974: Fig. 2; $c f$. Kale and Jacob, 1992). The curve describes oxygen fugacities in field II in the phase diagrams (see Fig. 2, 3);

IIIA: $\operatorname{ilm}(\mathrm{ss})=\operatorname{rut}(\mathrm{ss})+\mathrm{Fe}^{0}+\mathrm{O}_{2}$ for $T<1068^{\circ} \mathrm{C}$ (point $\mathrm{P}$; ibid.);

III: $\quad \mathrm{ilm}(\mathrm{ss})=\mathrm{fpb}(\mathrm{ss})+\mathrm{Fe}^{0}+\mathrm{O}_{2}$ for $T \geq 1068^{\circ} \mathrm{C}$ (ibid.).

\section{REFERENCES}

Adánez J., Cuadrat A., Abad A., Gayán P., De Diego L.F., García-Labiano F. (2010) Ilmenite activation during consecutive redox cycles in chemical looping combustion, Energ. Fuel. 24, 1402-1413.

Akimoto S., Nagata T., Katsura T. (1957) The $\mathrm{TiFe}_{2} \mathrm{O}_{5}-\mathrm{Ti}_{2} \mathrm{FeO}_{5}$ solid solution series, Nature (Lond.) 179, 37-38.
Anovitz L.M., Treiman A.H., Essene E.J., Hemingway B.S., Westrum E.F., Wall V.J., Burriel R., Bohlen S.R. (1985) The heat capacity of ilmenite and phase equilibria in the system Fe-Ti-O, Geochim. Cosmochim. Ac. 49, 10, 2027-2040.

Bartholomew R.F., White W.B. (1970) Growth of the intermediate oxides of titanium from borate fluxes under controlled oxygen fugacities, J. Cryst. Growth 6, 249-252.

Becher R.G. (1963) An improved process for the beneficiation of ores containing iron, Australian patent 247110. 
Berguerand N., Lyngfelt A. (2008a) Design and operation of a $10 \mathrm{~kW}_{\text {th }}$ chemical looping combustor for solid fuels-Testing with South African coal, Fuel 87, 2713-2726.

Berguerand N., Lyngfelt A. (2008b) The use of petroleum coke as fuel in a $10 \mathrm{~kW}_{\text {th }}$ chemical looping combustor, Int. J. Greenhouse Gas Control 2, 2, 169-179.

Berguerand N., Lyngfelt A. (2009) Operation in a $10 \mathrm{~kW}_{\text {th }}$ chemical looping combustor for solid fuel-Testing with a Mexican petroleum coke, Energy Procedia 1, 407-414.

Berguerand N., Lyngfelt A. (2010) Batch testing of solid fuels with ilmenite in a $10 \mathrm{~kW}_{\text {th }}$ chemical looping combustor, Fuel $\mathbf{8 9}$, 1749-1762.

Borowiec K., Rosenqvist T. (1981) Phase relations and oxidation studies in the system $\mathrm{Fe}-\mathrm{Fe}_{2} \mathrm{O}_{3}-\mathrm{TiO}_{2}$ at $700-1100^{\circ} \mathrm{C}$, Scand. $J$. Metall. 10, 217-224.

Borowiec K., Rosenqvist T. (1982) On the iron-titanium-magnesiumoxygen system, phase relations during reduction of Norwegian ilmenite, Report STF 34 A82100, Found. Sci. Ind. Res., Norweg. Inst. Technol., Trondheim.

Borowiec K., Rosenqvist T. (1985) Phase relations and oxygen potentials in the Fe-Ti-Mg-O system, Scand. J. Metall. 14, 33-43.

Buchdahl H.A. (1966) The Concepts of Classical Thermodynamics, Cambridge University Press, Cambridge.

Crystal D. (1985) A Dictionary of Linguistics and Phonetics, 2nd edition, Basil Blackwell, Oxford.

Cuadrat A., Abad A., Adánez J., De Diego L.F., García-Labiano F., Gayán P. (2010) Performance of ilmenite as oxygen carrier for chemical looping combustion using coal as fuel, Ist International Conference on Chemical Looping, Les Rencontres Scientifique de l'IFP, Lyon.

Darken L.S., Gurry R.W. (1945) The system iron-oxygen. I. The wüstite field and related equilibria, J. Am. Chem. Soc. 67, 8, 1398-1412.

Darken L.S., Gurry R.W. (1946) The system iron-oxygen. II. Equilibrium and thermodynamics of liquid oxide and other phases, J. Am. Chem. Soc. 68, 5, 798-816.

Deines P., Nafziger R.H., Ulmer G.C., Woermann E. (1974) Temperature-oxygen fugacity tables for selected gas mixtures in the system C-H-O at one atmosphere total pressure, Bull. Earth Mineral Sci.Exp. Station (88).

Den Hoed P. (1993) Matters mineral: The solid-state reduction of ilmenite, M.Sc.Eng. Dissertation, University of Natal, Durban, South Africa.

Den Hoed P., Luckos A. (2010) The oxidation and reduction of ilmenite in chemical looping combustion: A phase-chemical description, 1st International Conference on Chemical Looping, Les Rencontres Scientifique de l'IFP, Lyon.

De Vries R.C., Roy R. (1954) A phase diagram for the system $\mathrm{Ti}^{-} \mathrm{TiO}_{2}$ constructed from data in the literature, Ceram. Bull. 33, 12 , 370-372.

Ender A., Hofmann R., Stapper L., Dhupia G., Woermann E. (1980) Die Stabilität von Pseudobrookitmischkristallen, Fortschr. Mineral. 58, Suppl. 1, 26-28.

Eriksson G., Pelton A.D., Woermann E., Ender A. (1996) Measurement and thermodynamic evaluation of phase equilibria in the Fe-Ti-O system, Berichte Bunsengesellschaft Physikalische Chemie 100, 11, 1839-1849.

Fetisov V.B., Leont'yev L.I., Ivanova S.V., Belyayeva N.N., Kudinov B.Z. (1969) Mechanism of reduction or iron metatitanate (by hydrogen), Russ. Metall. 1, 47-50.

Grey I.E., Reid A.F. (1974) Reaction sequences in the reduction of ilmenite: 3-Reduction in a commercial rotary kiln; An X-ray diffraction study, T. I. Min. Metall. C 83, C39-46.
Grey I.E., Reid A.F., Jones D.G. (1974a) Reaction sequences in the reduction of ilmenite: 4 -Interpretation in terms of the $\mathrm{Fe}-\mathrm{Ti}-\mathrm{O}$ and $\mathrm{Fe}-\mathrm{Mn}-\mathrm{Ti}-\mathrm{O}$ phase diagrams, T. I. Min. Metall. C 83, C105-111.

Grey I.E., Li C., Reid A.F. (1974b) A thermodynamic study of iron in reduced rutile, J. Solid State Chem. 11, 120-127.

Grey I.E., Li C., Reid A.F. (1976) Phase equilibria in the system $\mathrm{MnO}-\mathrm{TiO}_{2}-\mathrm{Ti}_{2} \mathrm{O}_{3}$ at $1473 \mathrm{~K}$, J. Solid State Chem. 17, 343-352.

Grey I.E., Merritt R.R. (1981) Stability relations in the pseudobrookite solid solution $\mathrm{Fe}_{y} \mathrm{Ti}_{3-y} \mathrm{O}_{5}$, J. Solid State Chem. 37, 284-293.

Grey I.E., Ward J. (1973) An X-ray and Mössbauer study of the $\mathrm{FeTi}_{2} \mathrm{O}_{5}-\mathrm{Ti}_{3} \mathrm{O}_{5}$ system, J. Solid State Chem. 7, 300-307.

Gupta S.K., Rajakumar V., Grieveson P. (1989a) Phase relationships in the system $\mathrm{Fe}-\mathrm{Fe}_{2} \mathrm{O}_{3}-\mathrm{TiO}_{2}$ at 700 and $900^{\circ} \mathrm{C}$, Can. Metall. Quart. 28, 4, 331-335.

Haggerty S.E., Lindsley D.H. (1970) Stability of the pseudobrookite $\left(\mathrm{Fe}_{2} \mathrm{TiO}_{5}\right)$-ferropseudobrookite $\left(\mathrm{FeTi}_{2} \mathrm{O}_{5}\right)$ series, Carnegie Inst. Wash., Yearb. 1968-1969 68, 247-249.

Halliday M.A.K. (1961) Categories of the theory of grammar, Word 17, 3, 241-291.

Huxley J.S. (1938) Clines: An auxiliary taxonomic principle, Nature (Lond.) 142, 219-220.

Jerndal E., Leion H., Axelsson L., Ekvall T., Hedberg M., Johansson K., Källen M., Svensson R., Mattisson T., Lyngfelt A. (2011) Using low-cost iron-based materials as oxygen carriers for chemical looping combustion, Oil Gas Sci. Technol. In prep.

Jones D.G. (1973) Reaction sequences in the reduction of ilmenite: 2 -Gaseous reduction by carbon monoxide, T. I. Min. Metall. C 82, C186-192.

Jones D.G. (1974) Optical microscopy and electron-probe microanalysis study of ilmenite reduction, T. I. Min. Metall. C 83, C1-9.

Johnson R.E., Woermann E., Muan A. (1971) Equilibrium studies in the system MgO-“FeO"-TiO ${ }_{2}$, Am. J. Sci. 271, 278-292.

Kale G.M., Jacob K.T. (1992) Chemical potential of oxygen for iron-rutile-ilmenite and iron-ilmenite-ulvospinel equilibria, Metall. Trans. B 23B, 57-64.

Kolbitsch P., Pröll T., Mayer K., Bolhàr-Nordenkampf J., Hofbauer H. (2009) Operting experience with chemical looping combustion in a $120 \mathrm{~kW}$ dual circulating fluidized bed (DCFB) unit, Energy Procedia 1, 1465-1472.

Kowalski M., Spencer P.J., Neuschütz D. (1995) Phase diagrams, Verein Deutscher Eisenhüttenleute (VDEh) Slag Atlas, 2nd edition, Verlag Stahleisen GmbH, Düsseldorf.

Leion H., Mattisson T., Lyngfelt A. (2008a) Solid fuels in chemical looping combustion, Int. J. Greenhouse Gas Control 2, 180-193.

Leion H., Lyngfelt A., Johansson M., Jerndal E., Mattisson T. (2008b) The use of ilmenite as an oxygen carrier in chemical looping combustion, Chem. Eng. Res. Des. 86, 1017-1026.

Leion H., Mattisson T., Lyngfelt A. (2009) Use of ores and industrial products as oxygen carriers in chemical looping combustion, Energ. Fuel. 23, 2307-2315.

Levin E.M., McMurdie H.F. (1975) Phase Diagrams for Ceramists, 1975 Supplement, Columbus, Am. Ceram. Soc., Ohio.

Lindsley D.H. (1976a) The crystal chemistry and structure of oxide minerals as exemplified by the Fe-Ti oxides, in Reviews in Mineralogy, Vol. 3: Oxide Minerals, Rumble D. (ed.), Mineral. Soc. Am., Washington, pp. L1-60.

Lindsley D.H. (1976b) Experimental studies of oxide minerals, in Reviews in Mineralogy, Vol. 3: Oxide Minerals, Rumble D. (ed.), Mineral. Soc. Am., Washington, pp. L61-88.

Lindsley D.H. (1981) Some experiments pertaining to the magnetite -ulvöspinel miscibility gap, Am. Mineral.66, 759-762. 
Lindsley D.H. (1991) Experimental studies of oxide minerals, in Reviews in Mineralogy, Vol. 25: Oxide Minerals: Their Petrologic and Magnetic Significance, Lindsley D.H. (ed.), Mineral. Soc. Am., Washington, pp. 69-106.

Lyngfelt A. (2010) Oxygen carriers for chemical looping combustion-Operational experience, 1st International Conference on Chemical Looping, Les Rencontres Scientifique de l'IFP, Lyon.

MacChesney J.B., Muan A. (1959) Studies in the system iron oxide-titanium oxide, Am. Mineral. 44, 926-945.

Mayer K., Pröll T., Bolhàr-Nordenkampf J., Kolbitsch P., Hofbauer H. (2008) Chemical looping combustion in a $120 \mathrm{~kW}$ test rig First results, Poster presented at $C F B$ 9, 13-16 May, Hamburg.

Merritt R.R., Turnbull A.G. (1974) A solid-state cell study of oxygen activities in the Fe-Ti-O system, J. Solid State Chem. 10, 252-259.

Merritt R.R., Hyde B.G., Bursill L.A., Philp D.K. (1973) The thermodynamics of the titanium + oxygen system: An isothermal gravimetric study of the composition range $\mathrm{Ti}_{3} \mathrm{O}_{5}$ to $\mathrm{TiO}_{2}$ at $1304 \mathrm{~K}$, Philos. T. Roy. Soc. A 274, 627-661, plate 8.

Muan A. (1958) Phase equilibria at high temperatures in oxide systems involving changes in oxidation states, Am. J. Sci. 256, 171-207.

Muan A. (1970) The effect of oxygen pressure on phase relations in oxide systems, in Phase Diagrams: Materials Science and Technology, Vol. 2: The Use of Phase Diagrams in Metal, Refractory, Ceramic, and Cement Technology, Alper A.M. (ed.), Academic Press, New York, pp. 1-19.

OED (1989) The Oxford English Dictionary, 2nd edition, prepared by Simpson J.A., Weiner E.S.C., Oxford University Press.

O’Neill H.St C., Pownceby M.I., Wall V.J. (1988) Ilmenite-rutile-iron and ulvospinel-ilmenite-iron equilibria and the thermochemistry of ilmenite $\left(\mathrm{FeTiO}_{3}\right)$ and ulvospinel $\left(\mathrm{Fe}_{2} \mathrm{TiO}_{4}\right)$, Geochim. Cosmochim. Ac. 52, 8, 2065-2072.

Pauling L. (1930) The crystal structure of pseudobrookite, $Z$. Kristallogr. 73, 97-112.

Perreault P., Rifflart S., Patience G.-S. (2010) Ilmenite agglomeration during sequential oxidation-reduction, 1st International Conference on Chemical Looping, Les Rencontres Scientifique de l'IFP, Lyon.

Porter V.R. (1965) Studies in the titanium-oxygen system and the defect nature of rutile, PhD Dissertation, The Pennsylvania State University, University Park, PA.

Price G.D. (1981) Subsolidus phase relations in the titanomagnetite solid solution series, Am. Mineral. 66, 751-758.
Pröll T., Mayer K., Bolhàr-Nordenkampf J., Kolbitsch P., Mattisson T., Lyngfelt A., Hofbauer H. (2009) Natural minerals as oxygen carriers for chemical looping combustion in a dual circulating fluidized bed system, Energy Procedia 1, 27-34.

Reece M., Morrell R. (1991), Electron microscope study of nonstoichiometric titania, J. Mater. Sci 26, 20, 5666-5674.

Reid A.F., Ward J.C. (1971) Solid solution in the $\mathrm{FeTi}_{2} \mathrm{O}_{5}-\mathrm{Ti}_{3} \mathrm{O}_{5}$ system, Acta Chem. Scand. 25, 4, 1475-1476.

Saha P., Biggar G.M. (1974) Subsolidus reduction equilibria in the system Fe-Ti-O, Indian J. Earth Sci. 1, 1, 43-59.

Schwebel G.L., Wiedermann F., Krumm W. (2010) Reduction performance of ilmenite and hematite oxygen carriers in the context of a new CLC reactor concept, 1st International Conference on Chemical Looping, Les Rencontres Scientifique de l'IFP, Lyon.

Shchepëtkin A.A., Antonov V.K., Dvinin V.T., Chufarov G.I. (1968) Crystal chemical changes in the dissociation of iron titanate $\mathrm{Fe}_{2} \mathrm{TiO}_{4}$ under equilibrium conditions, Russ. J. Inorg. Chem. 13, 12, 1633-1634.

Simons B., Woermann E. (1978) Iron titanium oxides in equilibrium with metallic iron, Contrib. Mineral. Petr. 66, 81-89.

Spencer K.J., Lindsley D.H. (1981) A solution model for coexisting iron-titanium oxides, Am. Mineral. 66, 1189-1201.

Suzuki K., Sambongi K. (1972) High-temperature thermodynamic properties in the titanium-oxygen system, Tetsu To Hagane 58, 12, 1579-1593.

Taylor R.W. (1964) Phase equilibria in the system $\mathrm{FeO}-\mathrm{Fe}_{2} \mathrm{O}_{3}-\mathrm{TiO}_{2}$ at $1300^{\circ} \mathrm{C}$, Am. Mineral. 49, 1016-1030.

Taylor R.W., Schmalzried H. (1964) The free energy of formation of some titanates, silicates, and magnesium aluminate from measurements made with galvanic cells, J. Phys. Chem. 68, 9, 2444-2449.

Vincent E.A., Wright J.B., Chevallier R., Mathieu S. (1957) Heating experiments on some natural titaniferous magnetites, Mineral. Mag. 31, 624-655.

Wahlbeck P.G., Gilles P.W. (1966) Reinvestigation of the phase diagram for the system titanium-oxygen, J. Am. Ceram. Soc. 49, 4, 180-183.

Webster A.H., Bright N.F.H. (1961) The system iron-titaniumoxygen at $1200^{\circ} \mathrm{C}$ and oxygen partial pressures between 1 atm and $2 \times 10^{-14} \mathrm{~atm}$, J. Am. Ceram. Soc. 44, 3, 110-116.

Zador S. (1968) Non-stoichiometric measurements in dioxides of the rutile structure, in Electromotive Force Measurements in Hightemperature Systems, Alcock C.B. (ed.), Inst. Min. Metall., London, pp. $145-150$.

Final manuscript received in September 2010 Published online in April 2011 